ص ص[ [ ]

$$
\text { الحوافز وأثر ها علي الأداء }
$$

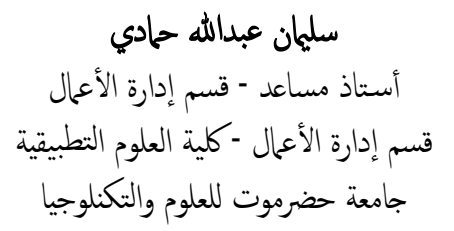

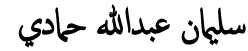

أستاذ مساعد - قسم إدارة الاعمال

جامعة حضرموت للعلوم والتكنلوجيا

\author{
الدكتور أنس عبد الباسط عباس \\ قسم إدارة الأعال - كلية العلوم التطبيقية \\ جامعة حضرموت للعلوم والتكنولوجيا
}

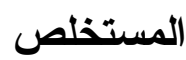

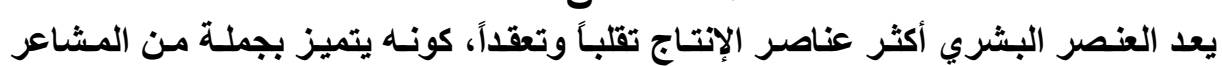

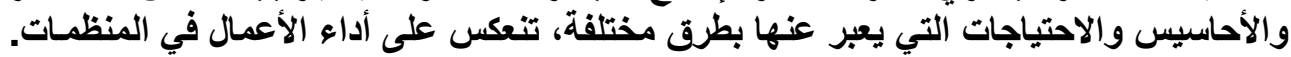

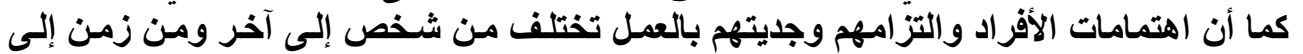

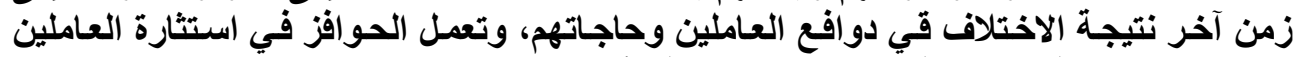

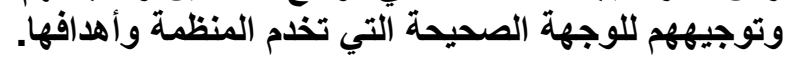

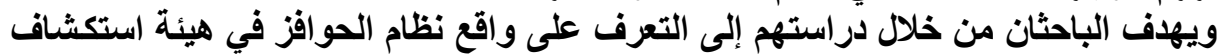

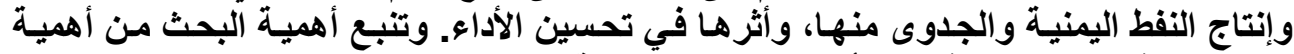

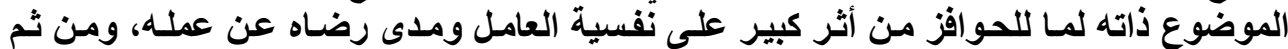

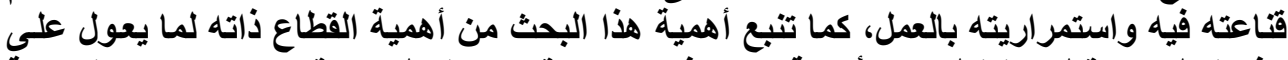

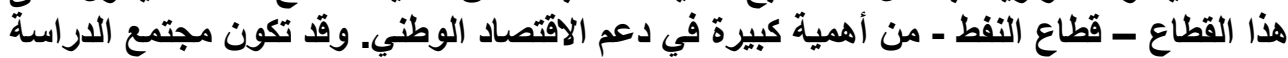

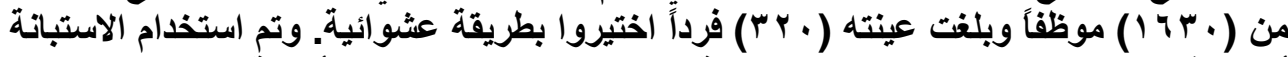

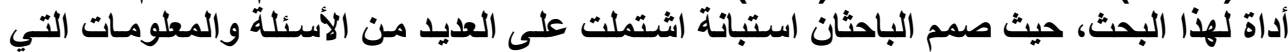

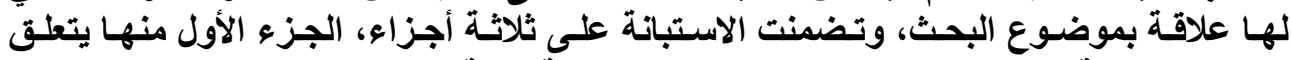

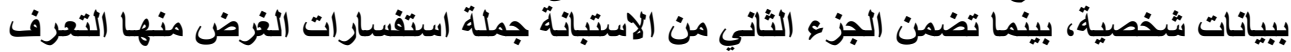

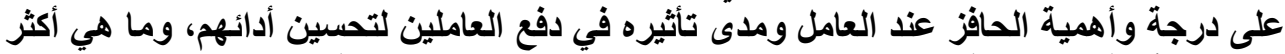

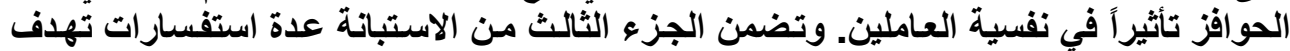

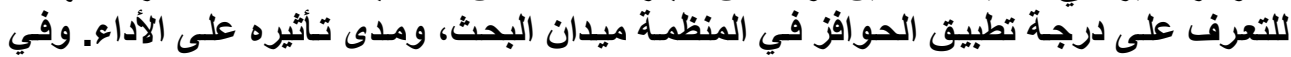

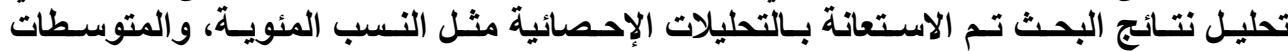

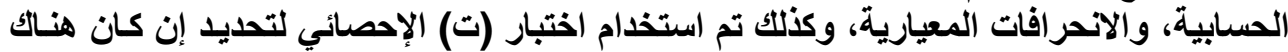

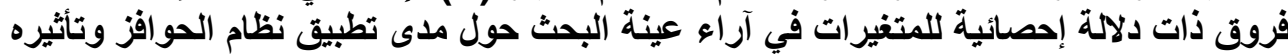

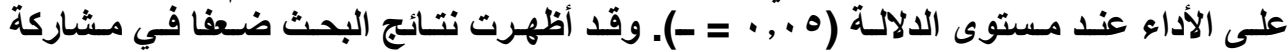

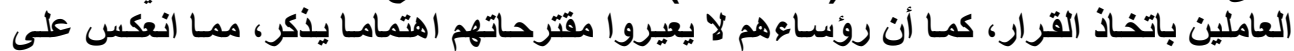

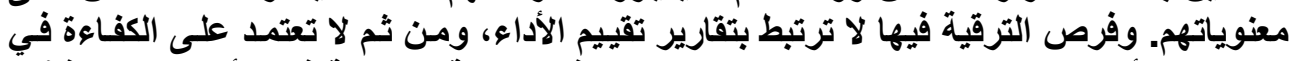

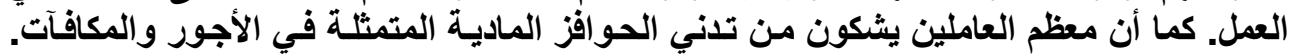

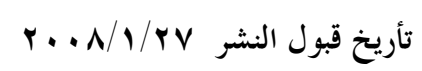

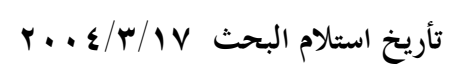




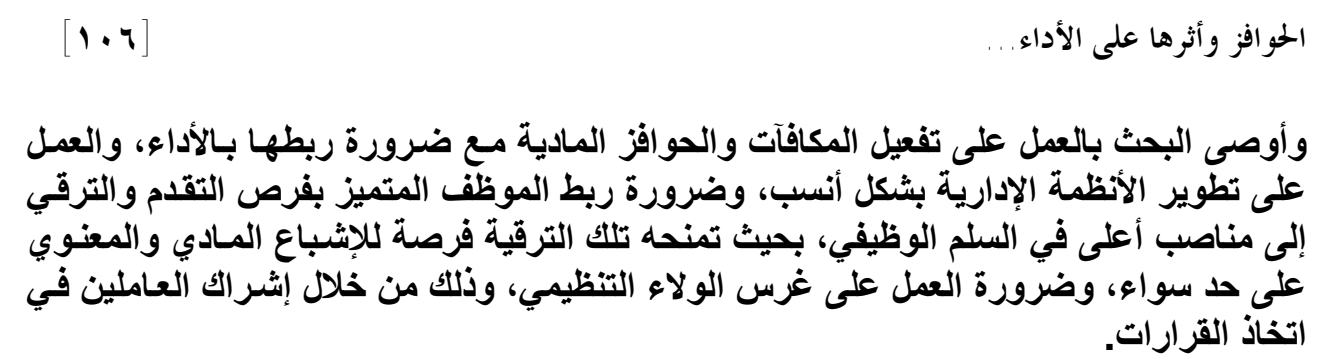

\title{
Incentives and Their Effect on Performance (A Field Study)
}

\author{
Anas A. Abbas (PhD) \\ Department of Business Administration \\ Hadhramout University of Sciences and \\ Technology
}

\author{
Slaiman A. Hummadi \\ Assistant Professor \\ Department of Business Administration \\ Hadhramout University of Sciences and \\ Technology
}

\begin{abstract}
Human resource considered as the most inconsistent variable in the production process as he has feelings and needs that he expresses in different ways, and which in turn, affect performance in organizations. Moreover, interests, commitment, and seriousness vary from one person to another and from one period to another as a result of the difference in motives and needs. Thus, incentives have a great role in motivating workers. The aim of this study is to explore the reality and utility of the incentives system in the Yemeni Corporation for Oil Drilling and Production. It also probes the impact incentives have upon performance improvement. The significance of this study springs from the impact incentives have upon the worker's career satisfaction. The sample of the study includes 320 employees chosen randomly from among 1630 who represent the total number of employees in that corporation. The questionnaire method has been adopted. This questionnaire consists of three parts. The first relates to the personal data, the second has to do with recognizing the extent to which incentives are significant for the employees and their impact on performance improvement and which kind of the incentives is the most rewarding for the employees, while the third explores the implementation of the incentives system in that corporation. For result analysis the researchers adopted statistical analyses such as Ratio, Averages, and Normative deviation. In addition, the T-test is used to determine whether or not there are any statistically significant differences the viewpoints of the sample concerning the implementation of the incentives system. The results indicate a meager role of the employees in the process of decision making. Moreover, chiefs pay only scant attention to the employee's suggestions, which negatively affect their drive. In addition, promotion chances are in no way related to the performance record. Further, most of the employees complain from the low level of bonuses. Finally, the study recommends activating bonuses and relating them to performance, adjusting and improving the administrative systems, adopting the promotion system, and strengthening the feeling of loyalty for the organization by getting the employees involved in the decision making process.
\end{abstract}




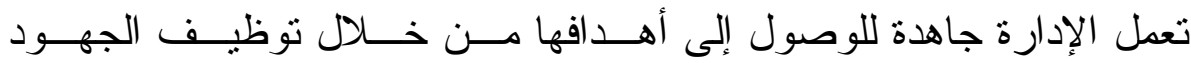

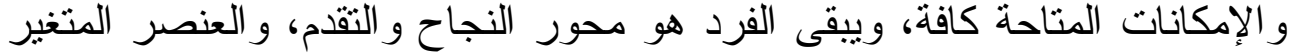

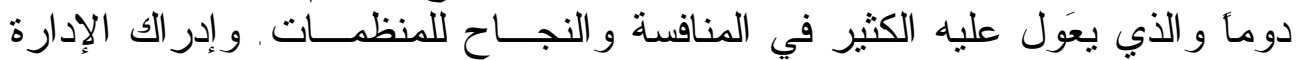

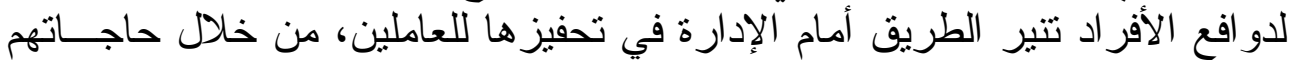

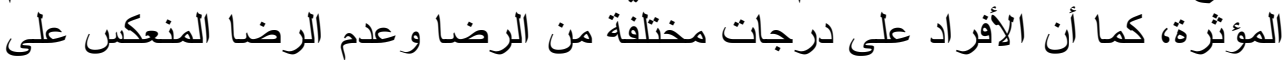

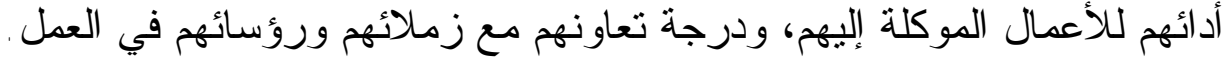

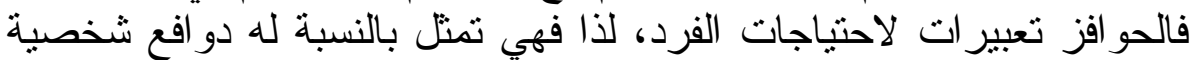

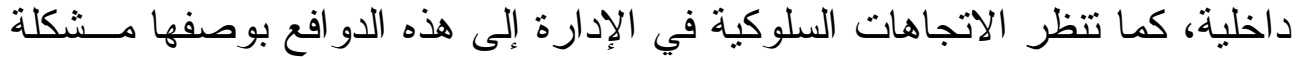

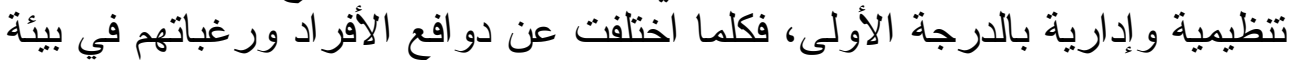

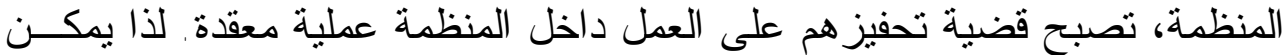

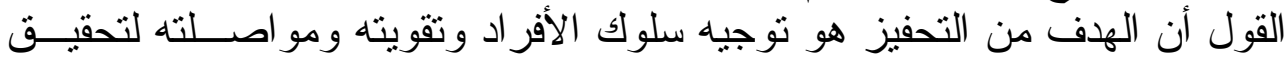

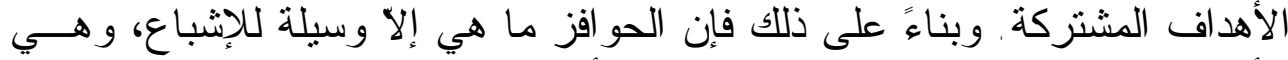

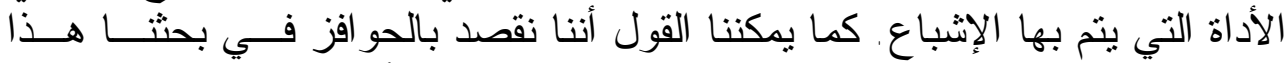

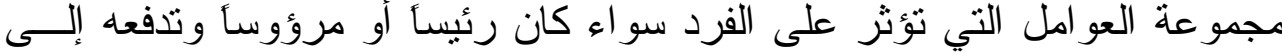

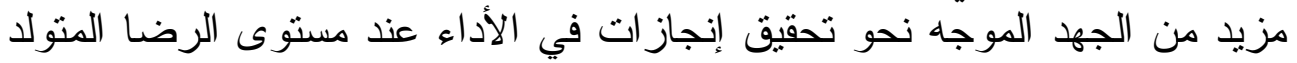

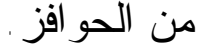

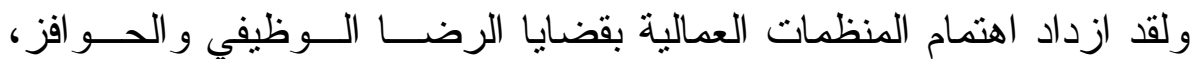

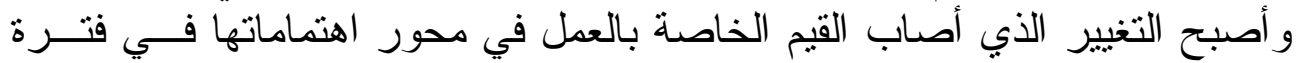

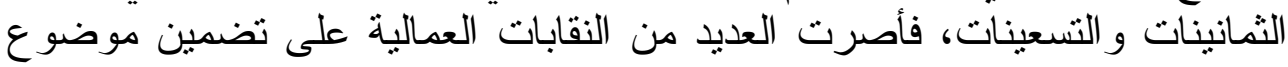

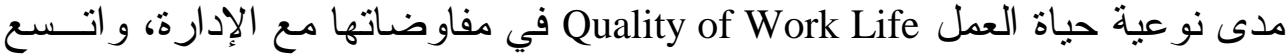

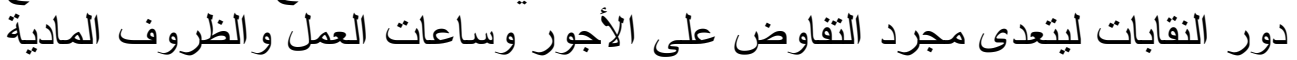

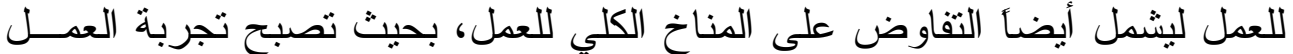

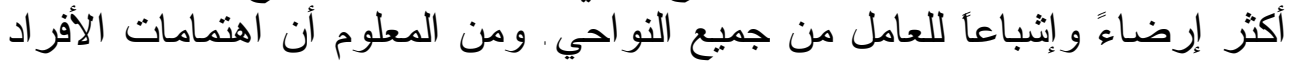

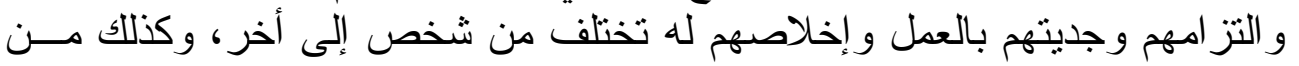

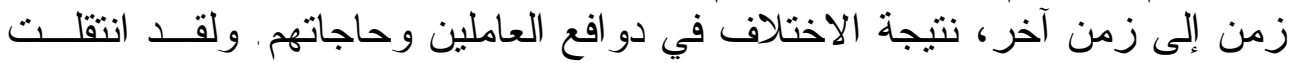

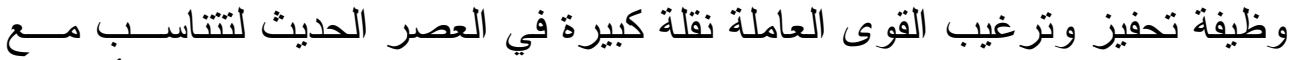

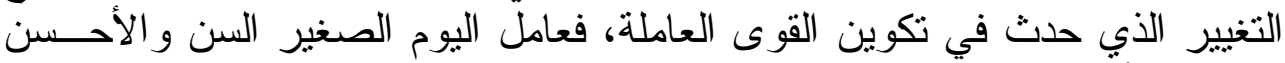

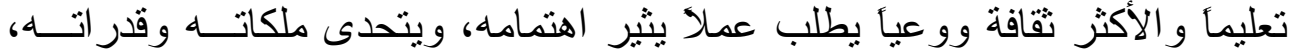
ويكون أكثر إثباعاً له.

\section{الار اسات السابقة}

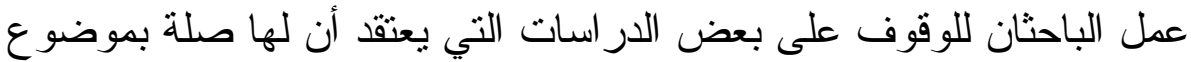

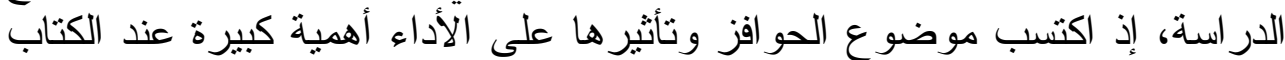

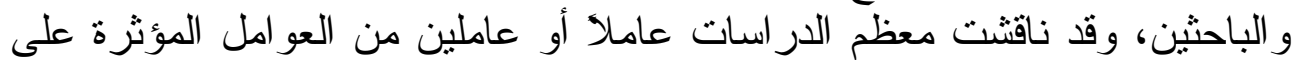

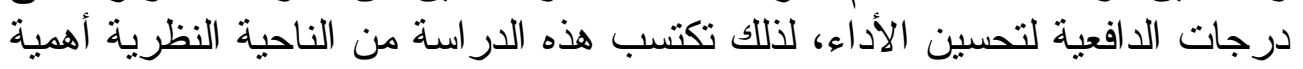




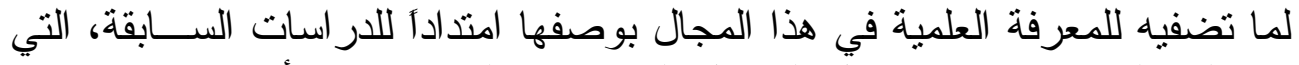

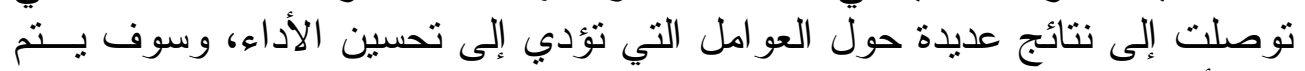

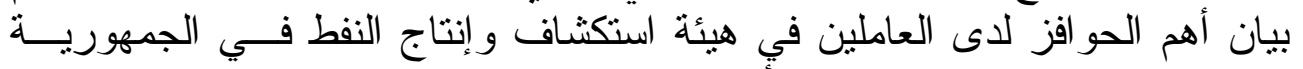

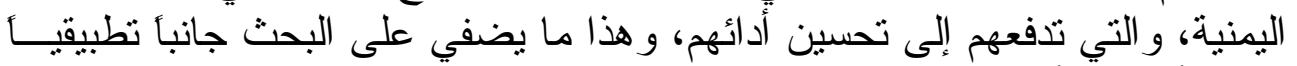

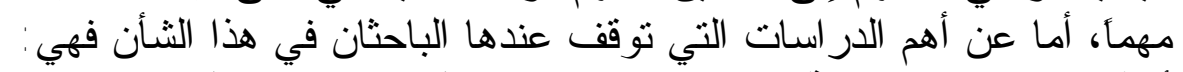

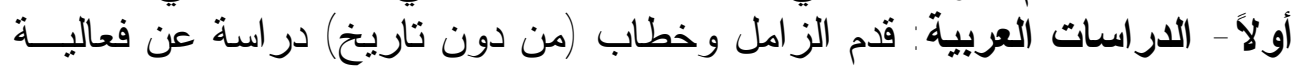

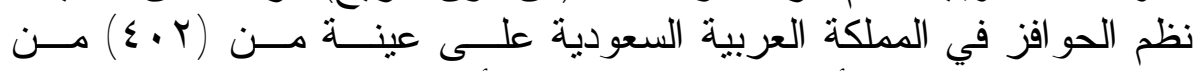

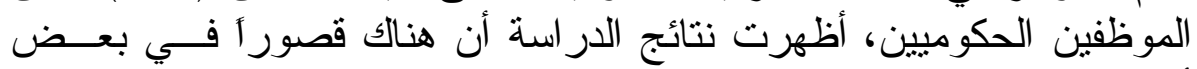

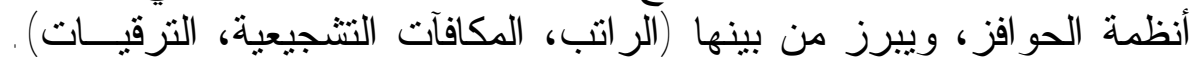

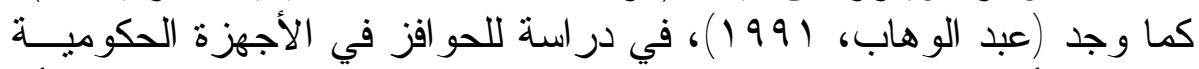

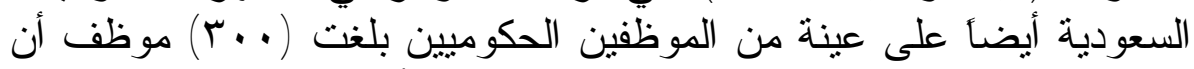

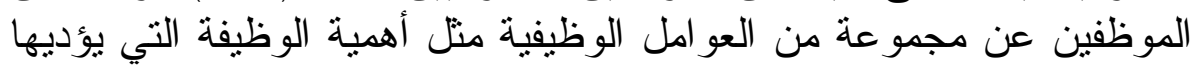

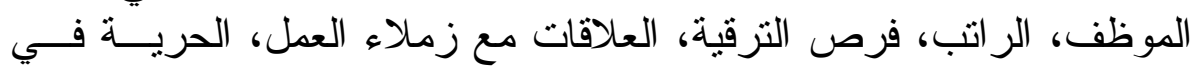
سماع الاقتر احات.

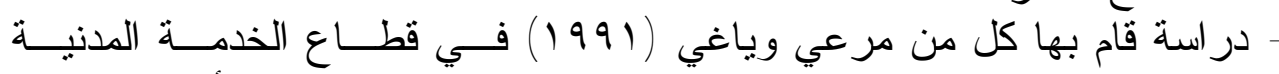

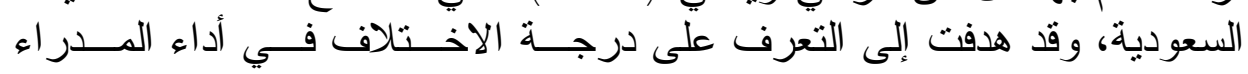

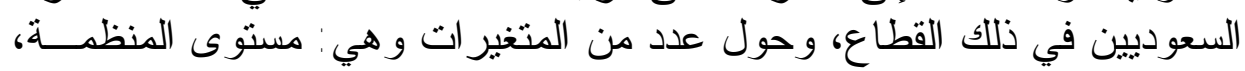

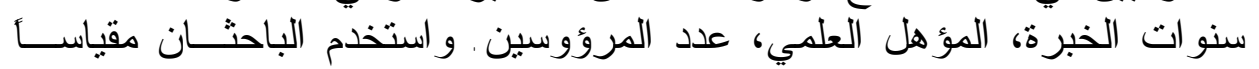

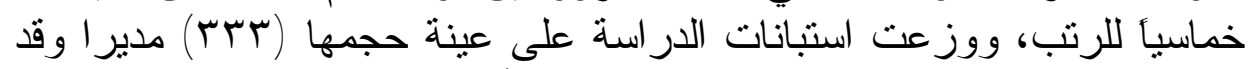

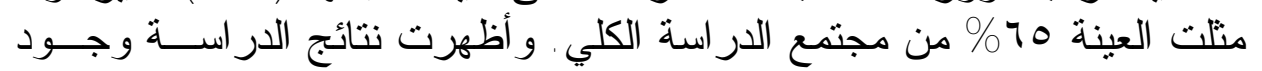

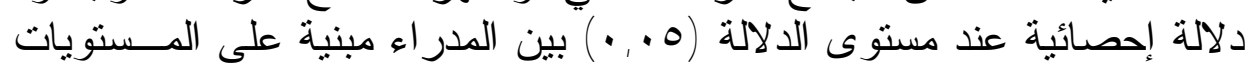

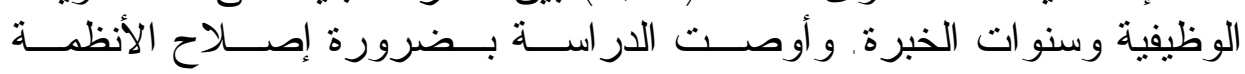

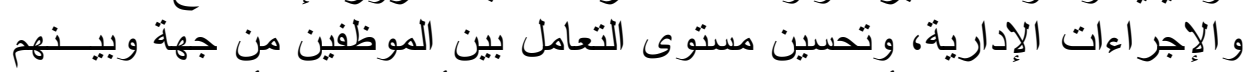

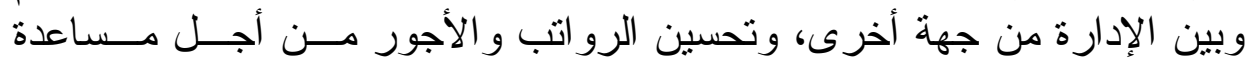

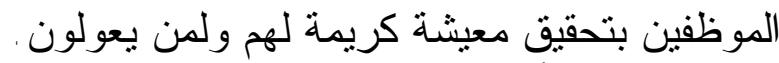

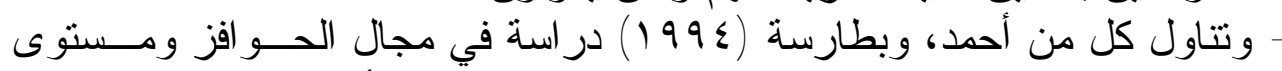

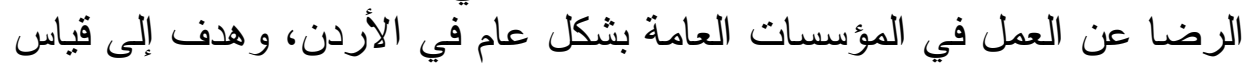

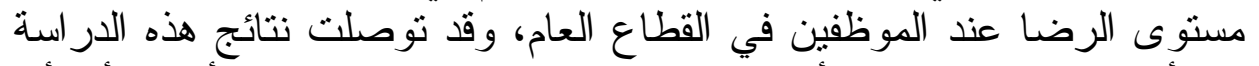

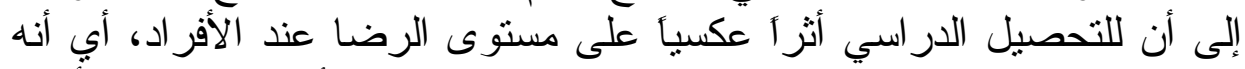

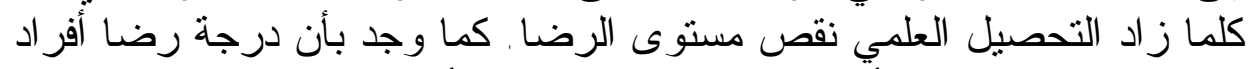

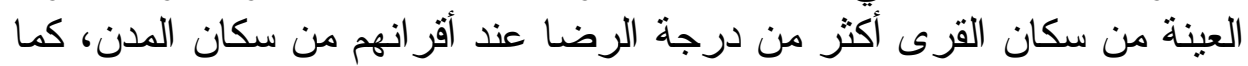

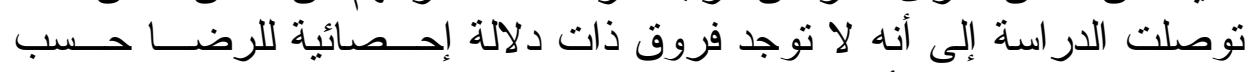

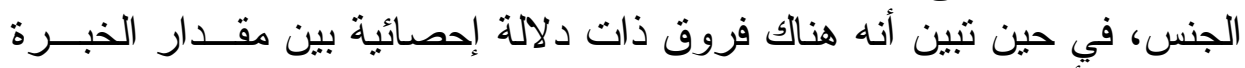

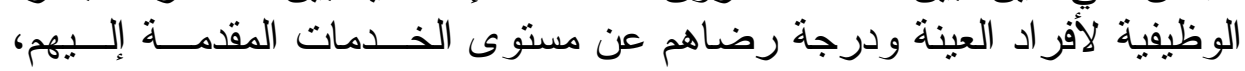

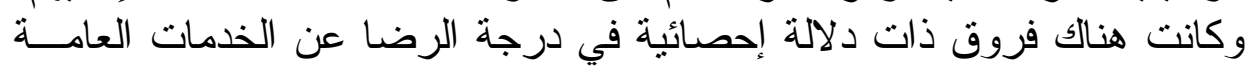

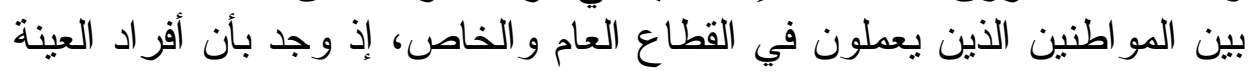




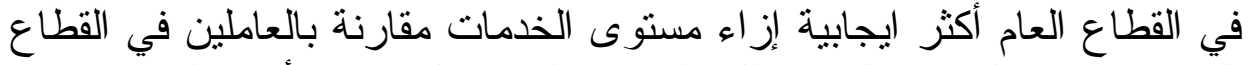

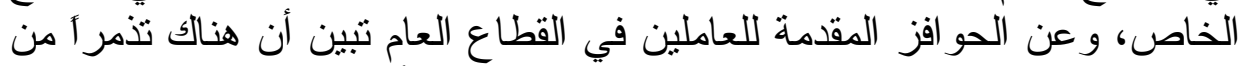

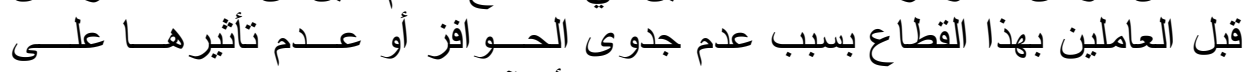

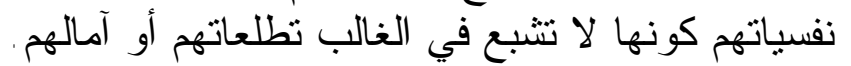

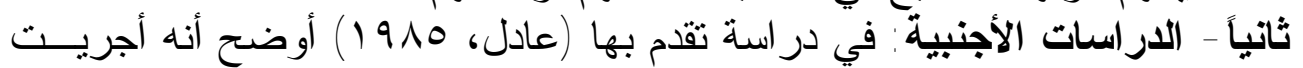

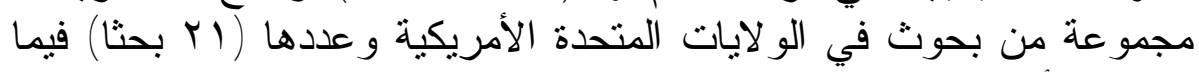

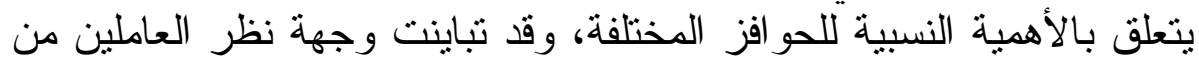

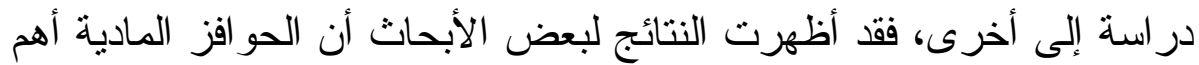

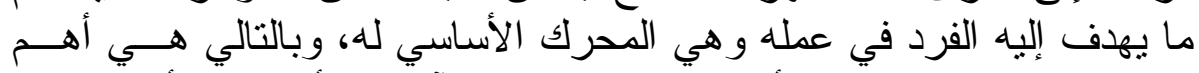

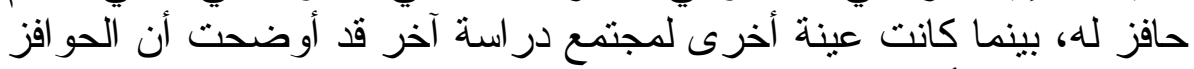

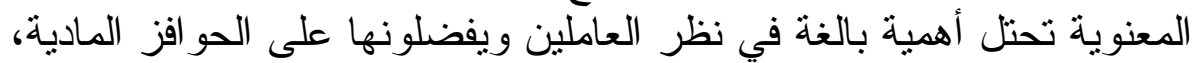

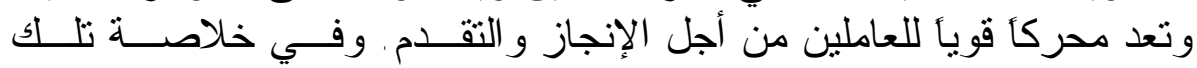

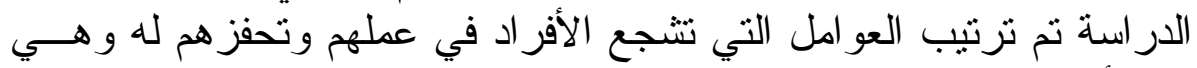

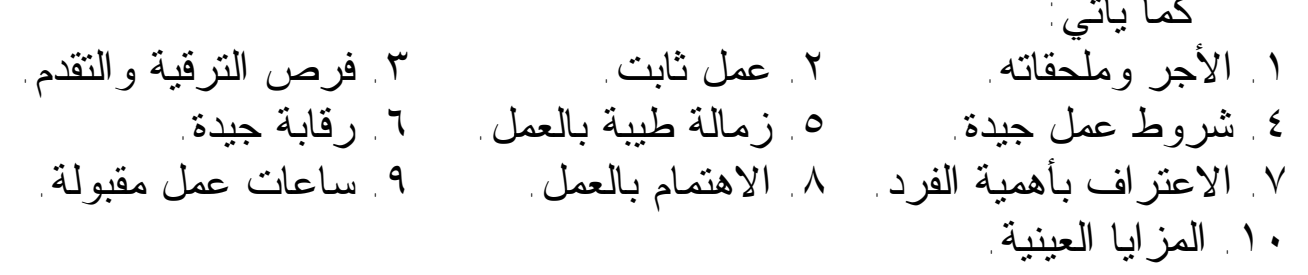

- مر اسة أجر اها ريغان (Reagan, 1986) في الو لايات المتحدة الأمريكية وبو لايسـة

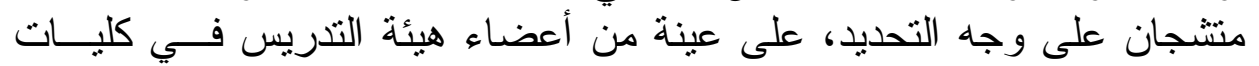

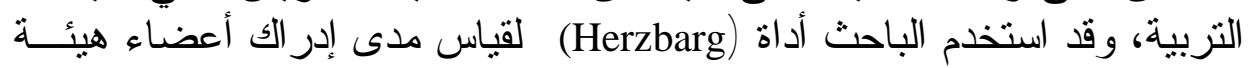

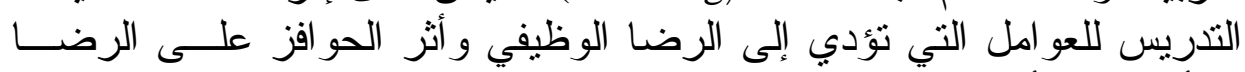

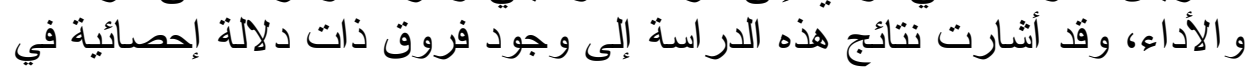

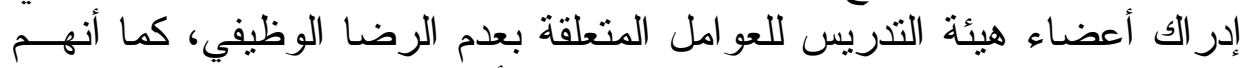

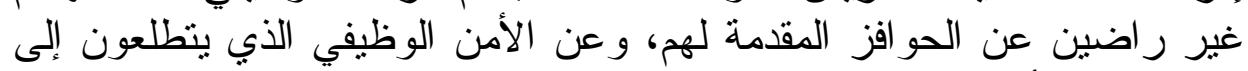

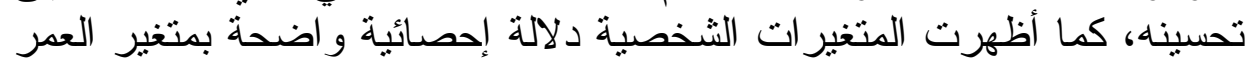

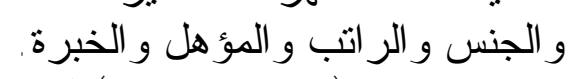

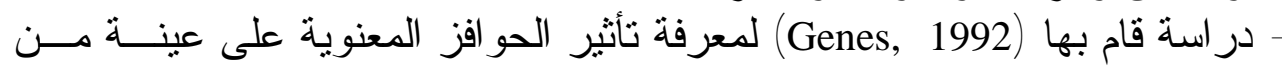

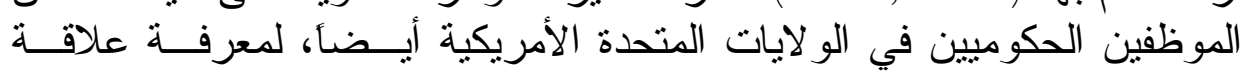

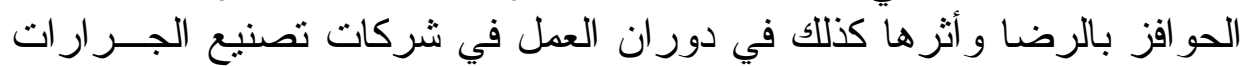

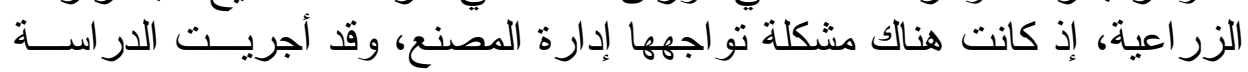

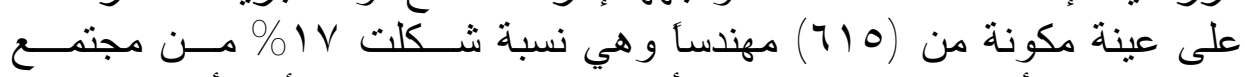

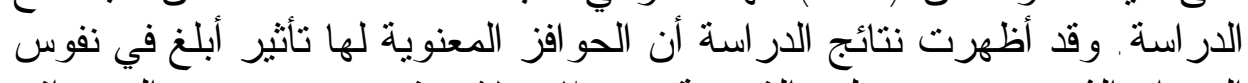

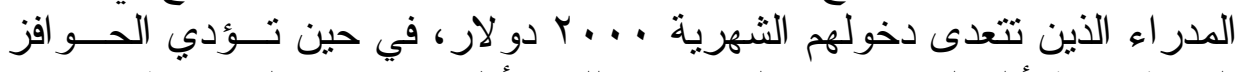

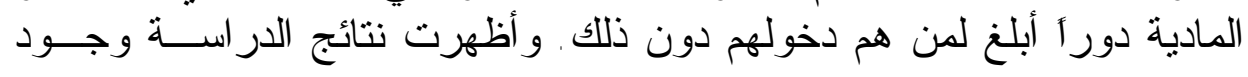




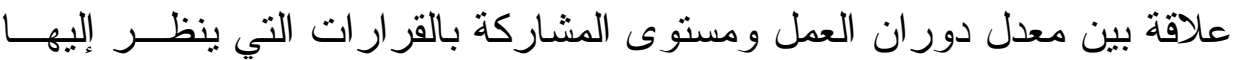

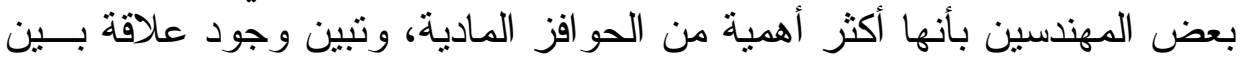

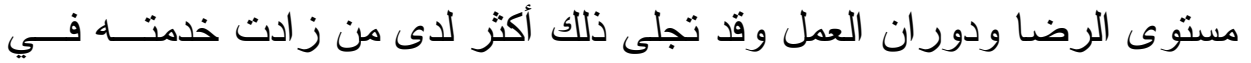

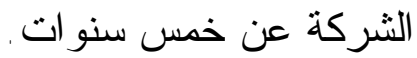

تعمل الإدارة جاهدة إلى تحسين أداء العاملين فيها ودفعهم تجـــاه الأهــــــاف

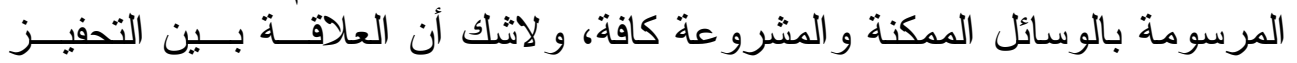

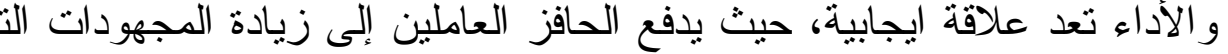

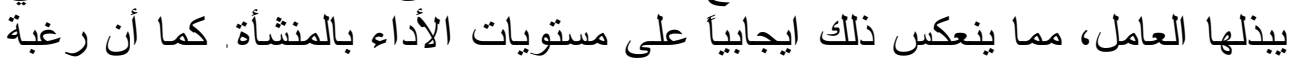

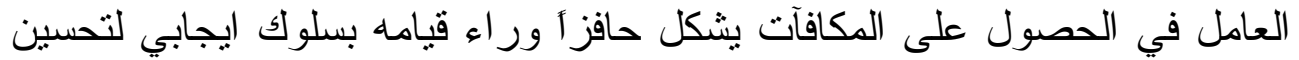

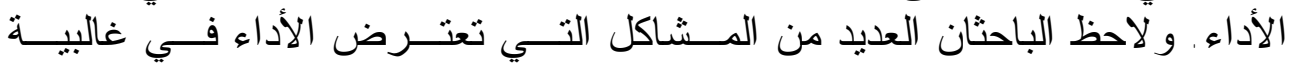

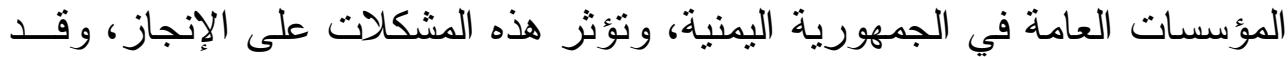

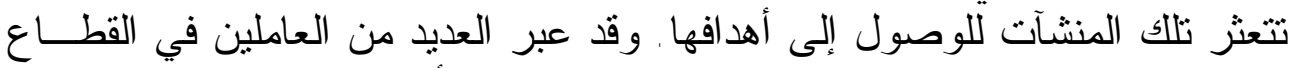

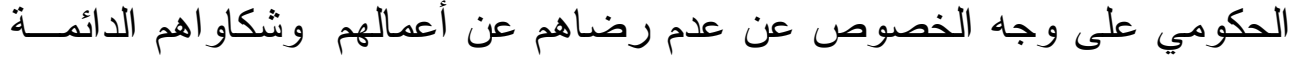

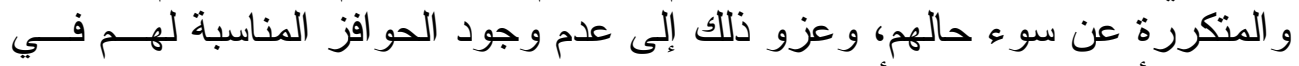

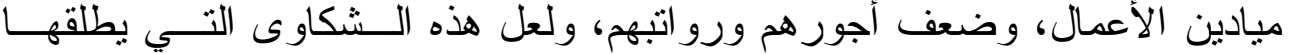

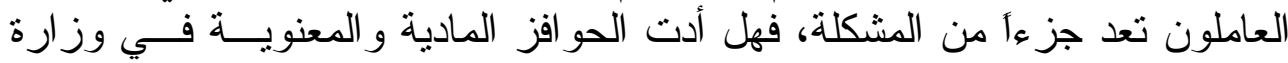

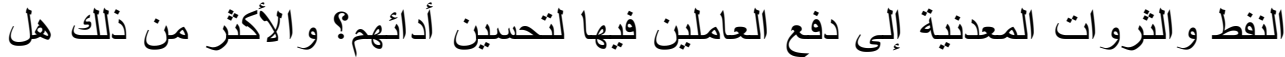

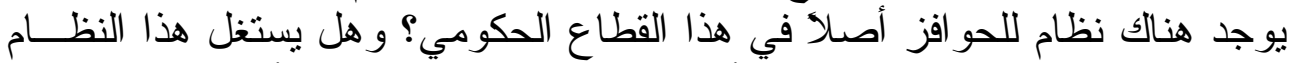

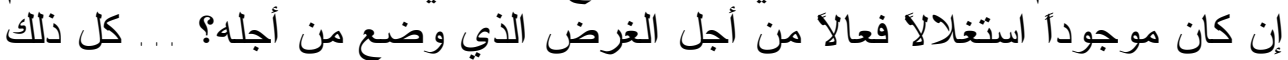

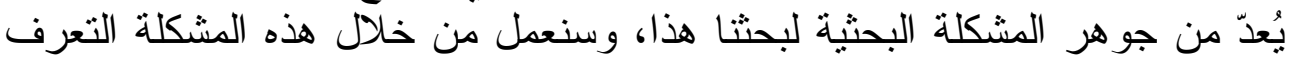

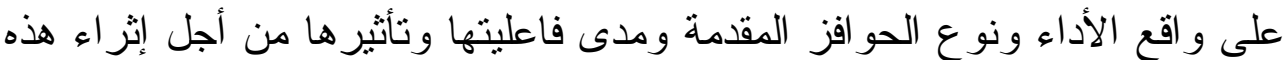

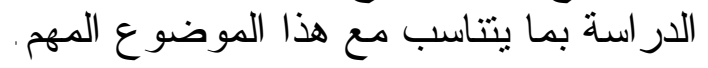

يمكن صياغة الفرضيات على النحو الآتي:

فرضيات البحث

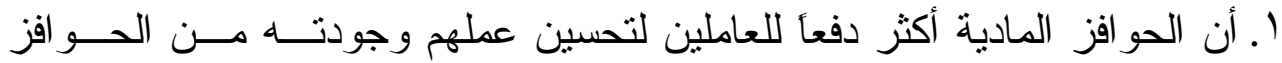

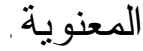
r r. هناك علاقة إيجابية بين درجة تطبيق نظام الحو افز ودرجة الأداء العام.

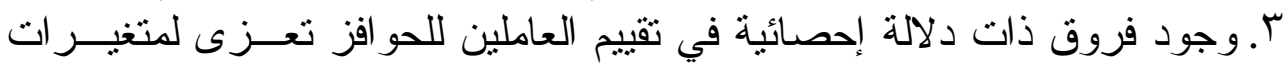
الخبرة، المؤهل، الحالة الاجتماعية، الدور لتهات التدريبية، العمر .

أهداف البحث

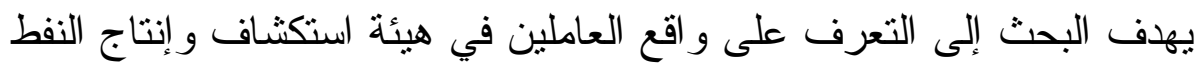
اليمنية الإداري، ومدى تفعيل نظم الحو افز و الدكافآت وتأثثير ذللك على الأداء، كمــــا 
تهدف إلى استطلاع أثز هذه الحوافز على الأداء عمومأ، وما هي أهم الحوافز التي

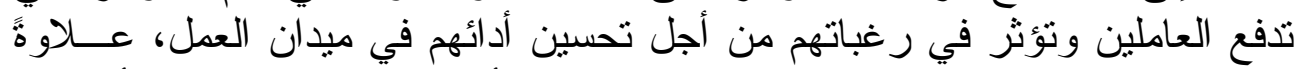

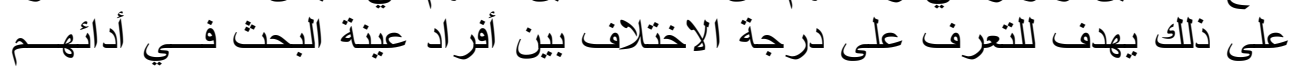

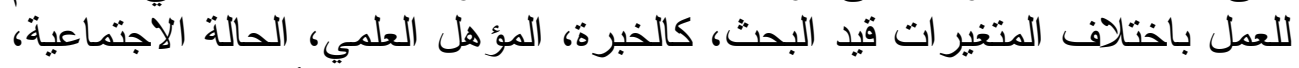

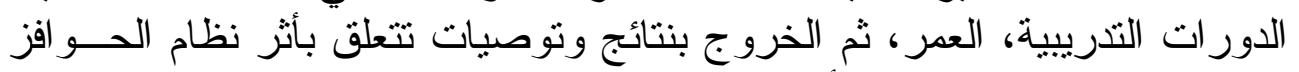

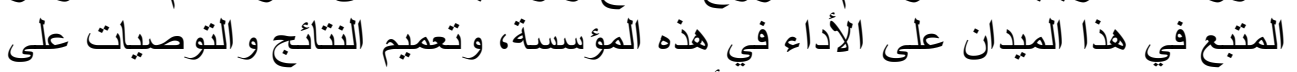
المؤسسات المتشابهة في الوسائل و الأساليب لتعم الفائدة قدر الإمكان في ذلكئ

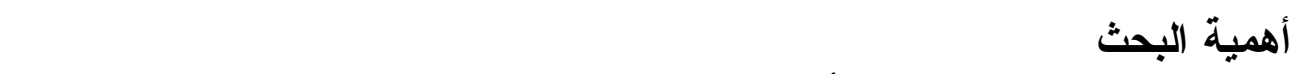
إن لكل فرد عامل في أي منظمة حاجات منتوعة، وحتى يتم تحفيز العاملين

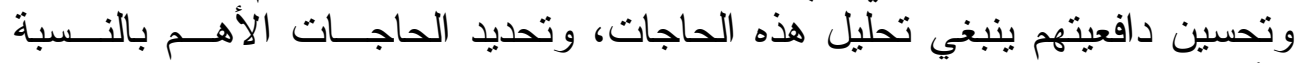

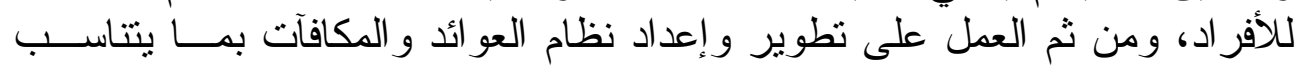

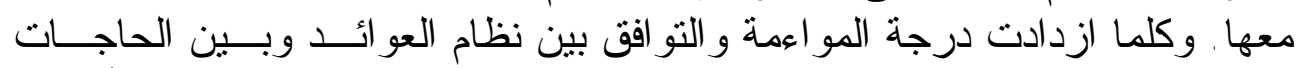

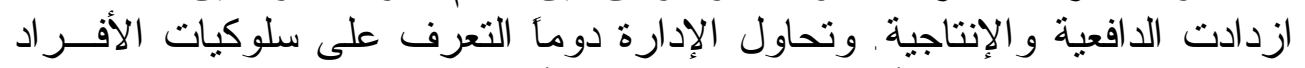

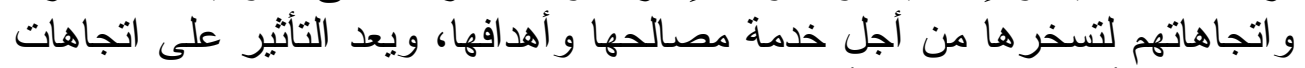

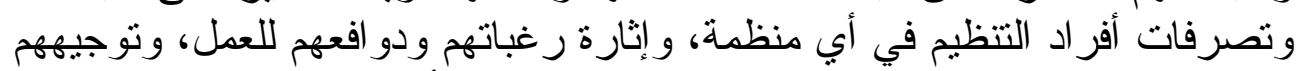

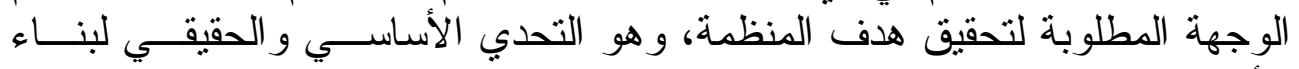

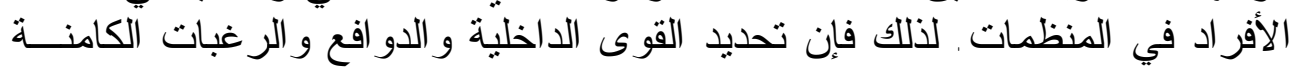

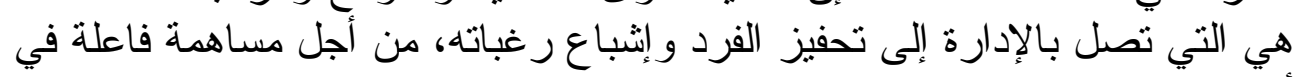

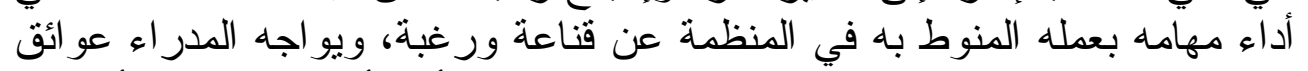

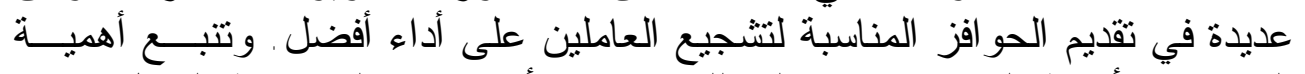

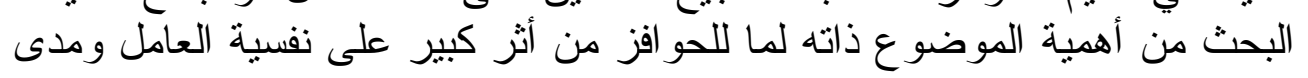

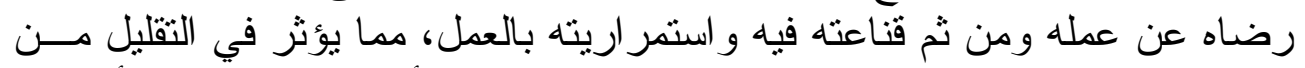

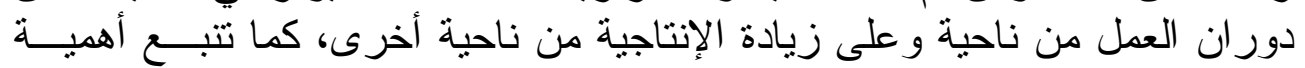

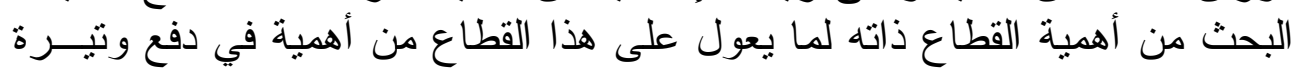

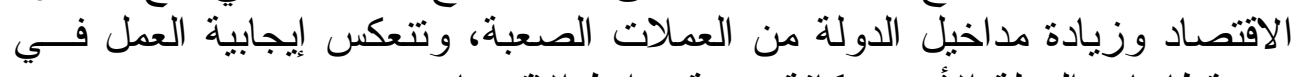

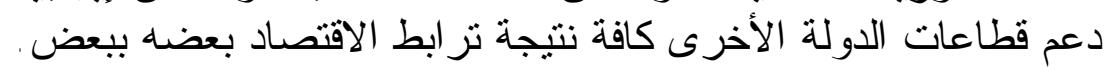

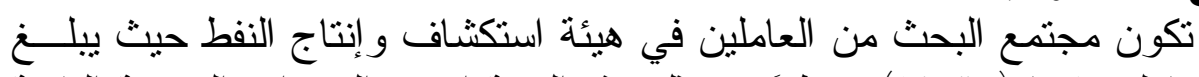

\section{مجتمع البحث وعينته}

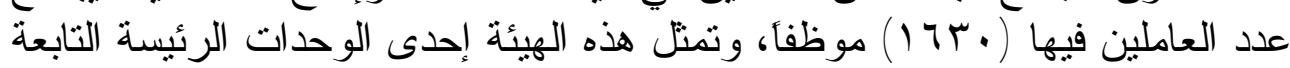

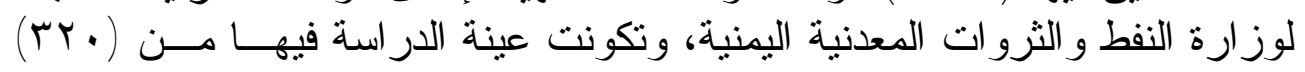

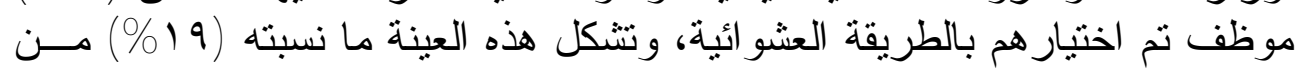

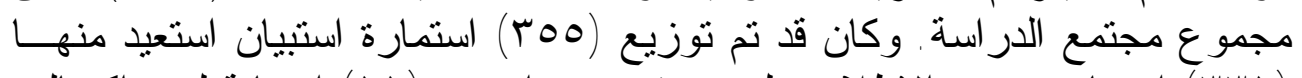
(1T) استمارة، وبعد الإطلاع عليهم وتفحصهم استبعد (1) (1) استبانة لعدم اكتمالهم

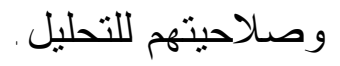




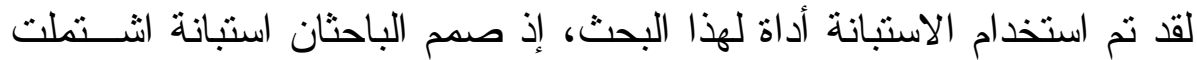

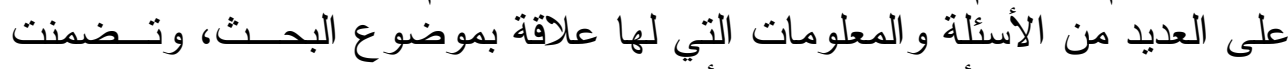

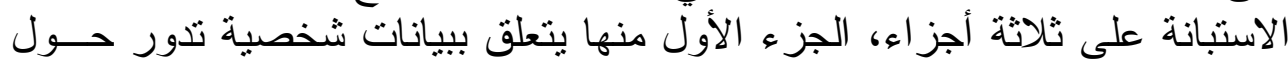

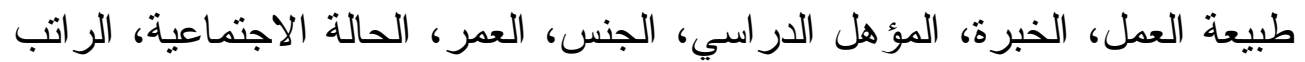

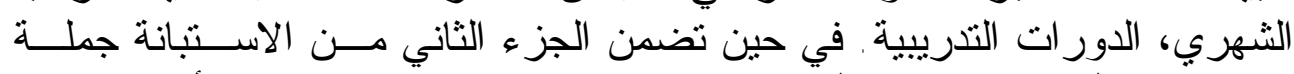

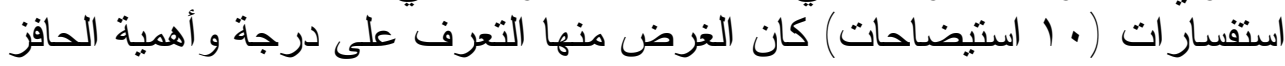

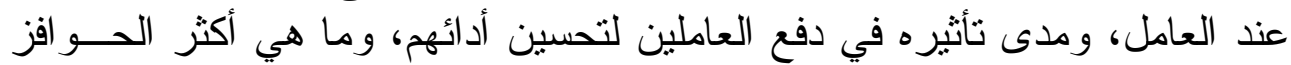

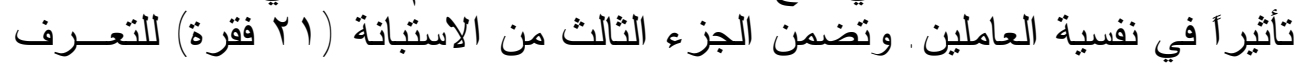

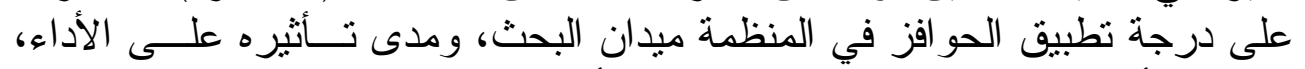

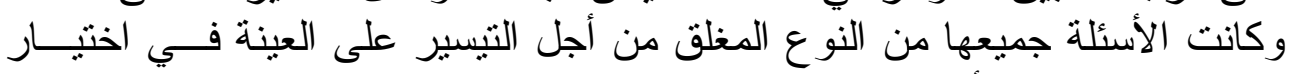

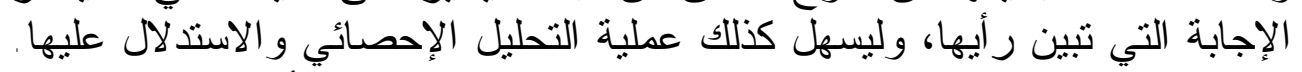

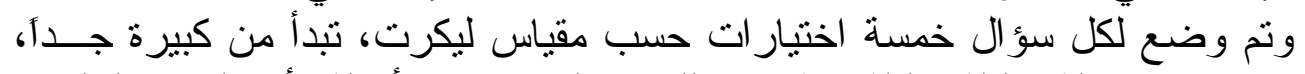

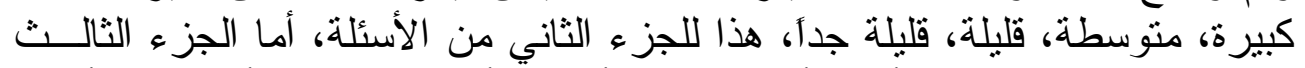

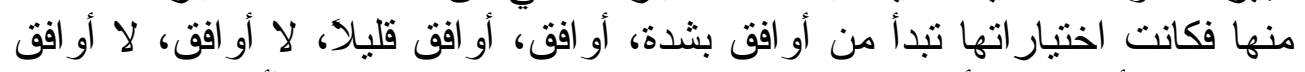

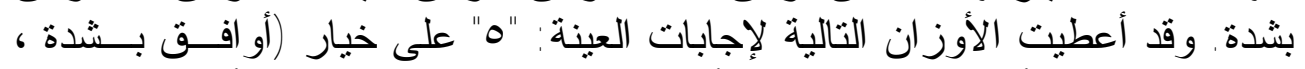

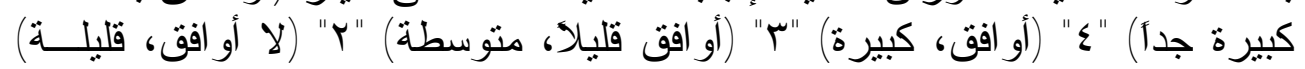
" ا" (لاؤ افق بشدة، قليلة جدأ) . (أفيرة

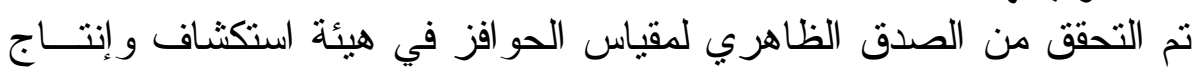
صدق الأداة وثباتها

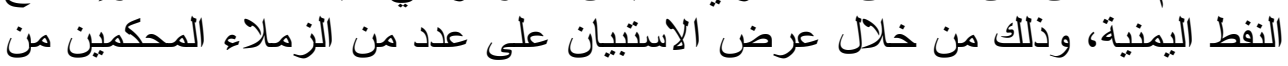

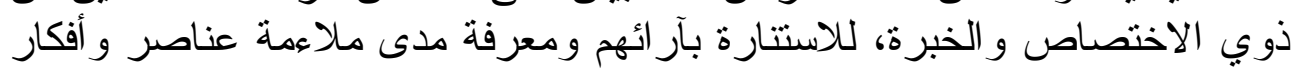

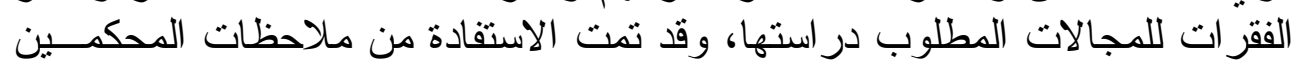

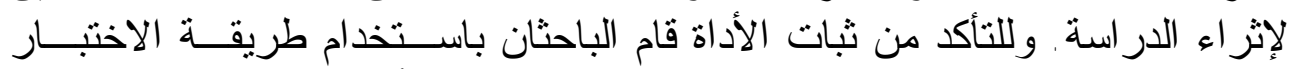

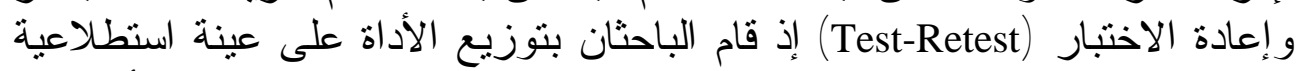

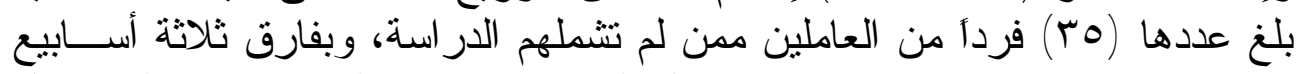

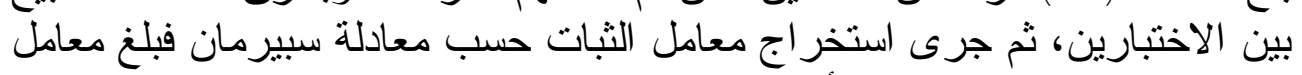

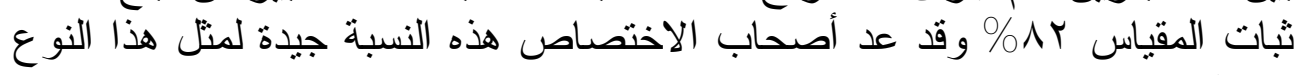

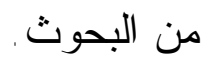

\section{المعالجة الإحصائية}

بعد تجميع البيانات الأساسية عمل الباحثان على تحويل البيانات الأساسية إلى إلى

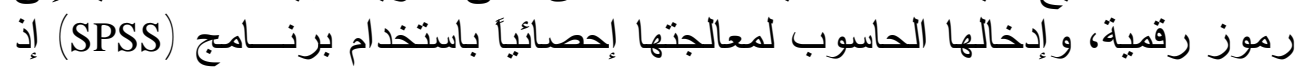

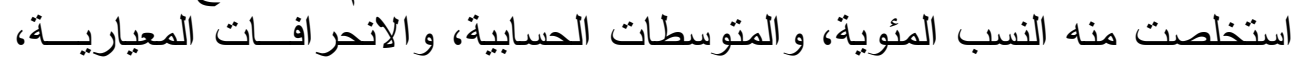

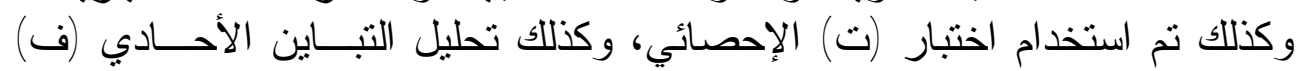




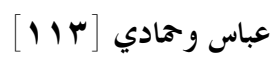

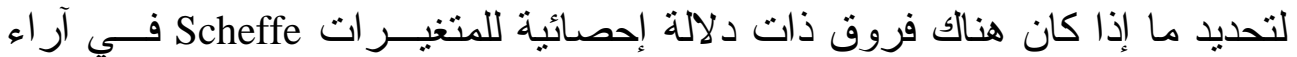

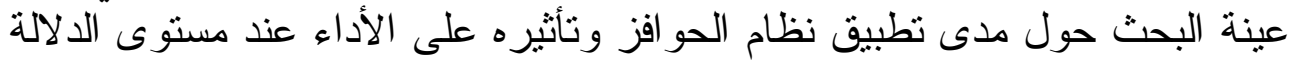

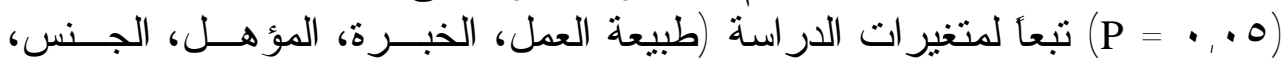
العمر ، الحالة الاجتماعية، الر اتب الثهري، الدئن الدورات التدريبية).

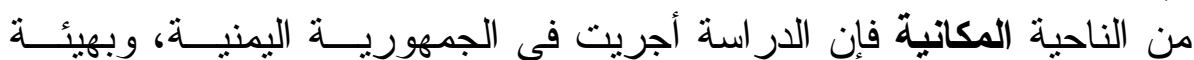

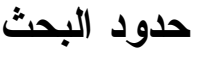

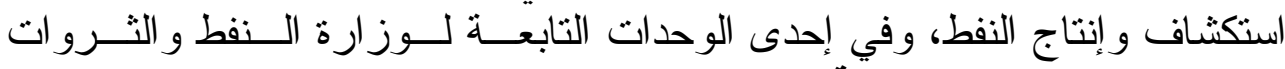
المعدنية. ومن الناحية الزمنية فقد تمت الدر اسة خلال العام بـ . ب ميلادي.

\section{عرض البيانات وتحليلها}

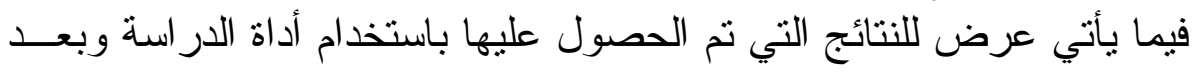

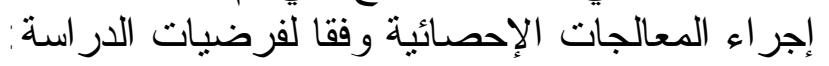

أولاً - مدى أهمية الحوافز في دفع العاملين إلى تحسين الأداء

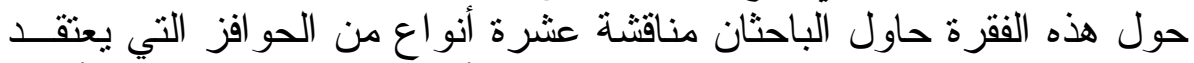

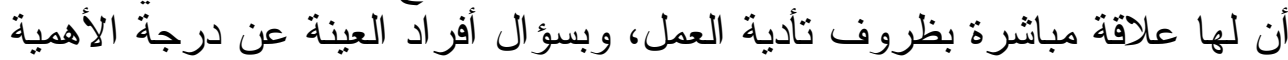

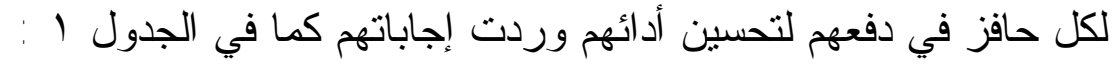

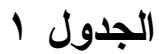

المتوسط والاحر اف المعياري ودرجة الأهية للحوافز مرتبة تنازليا حسب رأي أفز اد العينة

\begin{tabular}{|c|c|c|c|c|c|}
\hline الأهمبة & اللمتوسط الأعلى & اللمتوسط الأدنى & الحستبي & الالحياري & نوع الحافز \\
\hline كبيرة & $\varepsilon, \varepsilon r Y$ & $\varepsilon, \cdot 11$ & $\varepsilon, Y 07$ & $\cdot, \vee 9 \wedge$ & العلاقة مع الزملاء \\
\hline كبيرة & $r, V \vee T$ & r, rYo & $r, 0 \leq q$ & $1, \cdot r_{0}$ & العلاقة مع الرؤساء \\
\hline متوسطة & $r, \varepsilon Y \wedge$ & r,97r & $r, 190$ & $1, .09$ & الاستقر ار الوظيفي \\
\hline متوسطة & $r, \varepsilon, \varepsilon$ & r,Ar. & $r, I Y r$ & 1, MY & أهمية العمل \\
\hline متوسطة & $r, \Lambda \cdot r$ & $r, r 19$ & $r, 071$ & $1,1 \cdot 1$ & تقدير الجهود \\
\hline قليلة & $r, 791$ & $r, r \cdot \varepsilon$ & $r, \leqslant 01$ & $1,1 Y \varepsilon$ & التقدم و الترقي بالعمل \\
\hline قليلة & Y,TYI & $r, 109$ & $r, r q$. & $1, .01$ & الصلاحيات الممنوحة \\
\hline قليلة & $T, 10 V$ & $1, V \vee$. & $1,97 \varepsilon$ & $\cdot, \wedge \wedge 1$ & الخدمات و المز ايا \\
\hline قليلة & Y,177 & 1,100 & 1,971 & $\cdot, 9 \leq 9$ & الأجر و الحو افز المادية \\
\hline قليلة & T,17. & 1,101 & 1,907 & $\cdot, 9 \cdot \varepsilon$ & الحوافز العينية \\
\hline
\end{tabular}


يتضح من الجدول ا أنه على الرغم من أن العلاقات الاجتماعية السائدة بين

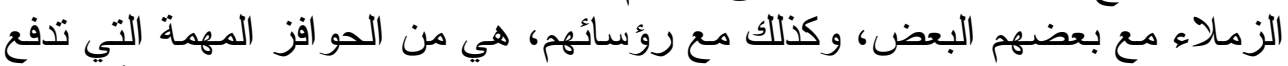

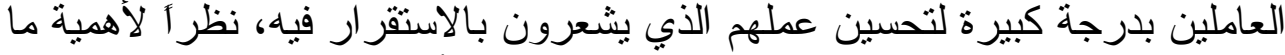

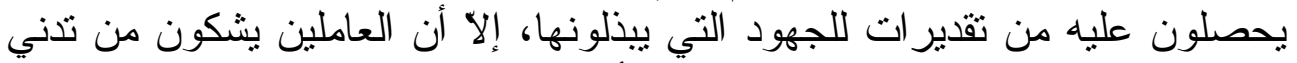

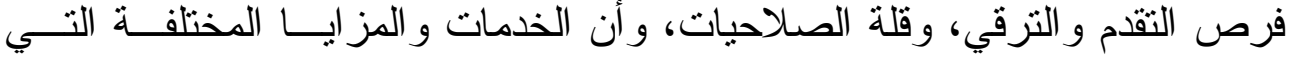

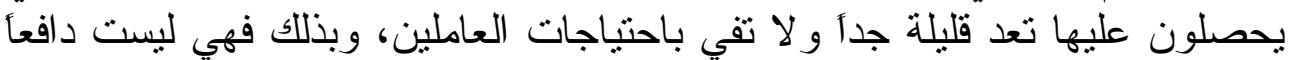

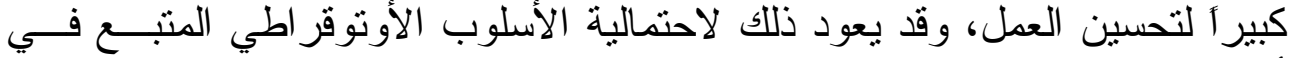

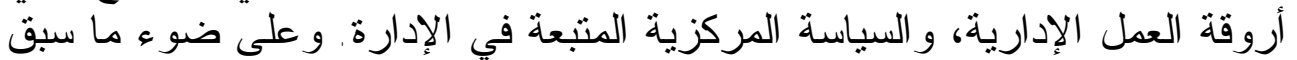

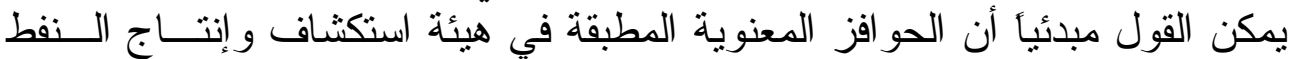

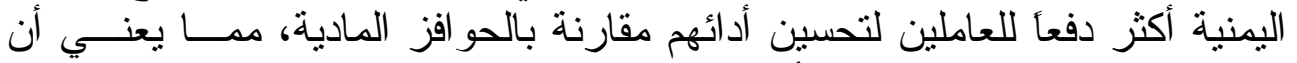

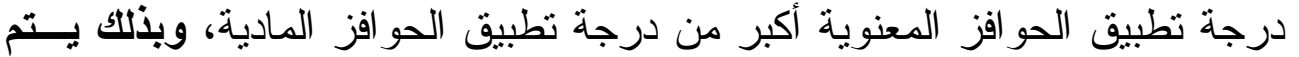

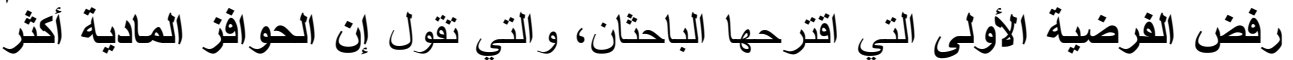
دفعا للعاملين لتحسين عملهم وجودته من الحوالفز الفز المعنوية.

\section{ثانياً - مدى تطبيق نظام الحو افز وتأثيره في الأداء}

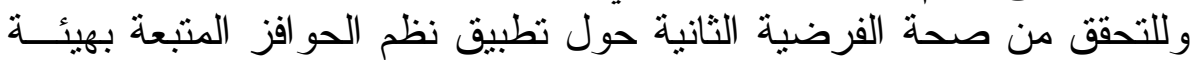

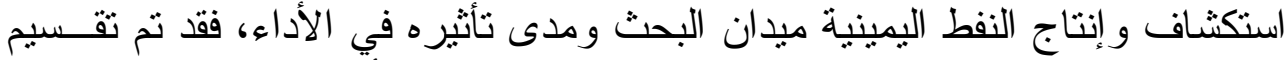

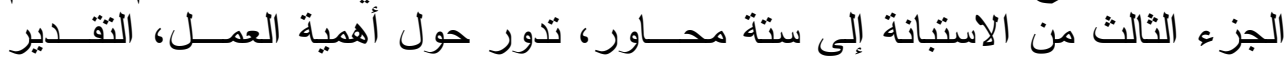

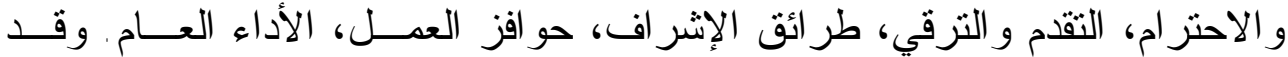

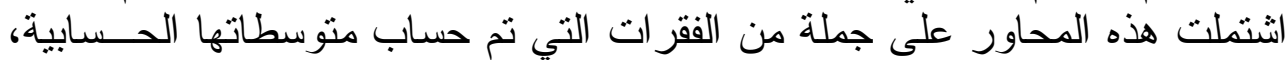

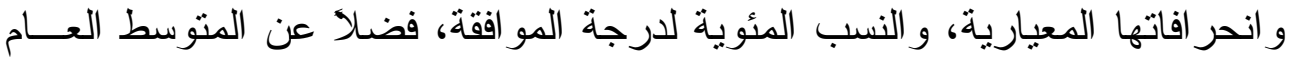

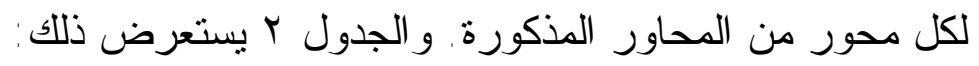

\begin{tabular}{|c|c|c|c|c|c|c|}
\hline \multicolumn{7}{|c|}{ المتوسط الاحر اف المعياري والنسبة المئوية و الترتيب لمحاور الفرضية الثانية } \\
\hline اللقظظي & النسبة \% & المعياري & المسابي المتوسط & 霄: & 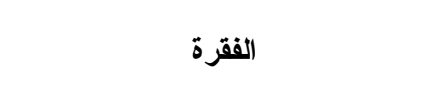 & المحور \\
\hline كبيرة & $V \cdot, V \varepsilon$ & $1, \cdot r r$ & $r, 0 r V$ & 0 & إنجاز كك للعمل يحفز كك لتحسين الأداء & \multirow{3}{*}{ 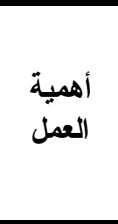 } \\
\hline قليلة & $71,0 \leqslant$ & 1,174 & $r, \varepsilon r V$ & $\bar{v}$ & 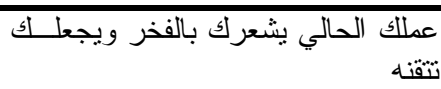 & \\
\hline كبيرة & $V 7, r \varepsilon$ & $1, \cdot \leqslant \varepsilon$ & $r, \Lambda \mid V$ & $\bar{r}$ & بحماس للعمل الحــالي يــفعك للعمـل & \\
\hline 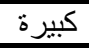 & $\overline{V I, Y Y}$ & $\cdot, 990$ & $r, 071$ & $\varepsilon$ & تقدير رؤسائك يدفعك لتحسين عملك & \multirow{3}{*}{ و الاحتر ام } \\
\hline قليلة & $\overline{T 1, Y Y}$ & $\cdot, 990$ & $r, \cdot 71$ & 11 & تعترف الإدارة بأهمية الفرد المتميز & \\
\hline منعدمة & $\varepsilon 7,1$. & $\overline{T, \cdot Y V}$ & $r, r \cdot 0$ & 19 & اقتز احات العاملين تؤخذ بعين الاعتبار & \\
\hline 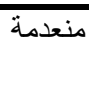 & $\varepsilon \wedge, \cdot \varepsilon$ & $1, \cdot \wedge V$ & $r, \varepsilon \cdot r$ & IV & 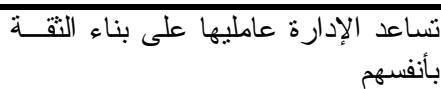 & و التزقيمي \\
\hline
\end{tabular}




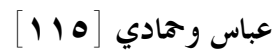

\begin{tabular}{|c|c|c|c|c|c|c|}
\hline التفظير & النسبة \% & الالمعراف & المستوسط & 㝵: & 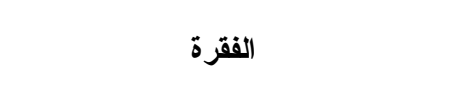 & المحور \\
\hline كبيرة & $\vee \wedge, \cdot \varepsilon$ & $1, I V Y$ & $r, q \cdot r$ & 1 & 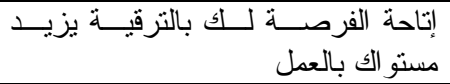 & \\
\hline منعدمة & $\leqslant 0, \wedge \uparrow$ & $1, \cdot \leqslant \wedge$ & $r, Y q r$ & $r \cdot$ & بوجد ارتباط و اضح بين الترقية و الأداء & \\
\hline قليلة & or, ,1 & 1, TrO & $r, 709$ & 10 & إن تلى الأداء & \\
\hline قليلة & $71,0 \leq$ & 1,100 & $r, \varepsilon r V$ & 7 & طريقة الإشر اف المتبعة تذعوك لعــدم & \multirow{3}{*}{ طر الإشر افق } \\
\hline منعدمة & $\left.\sum V, 0\right\rceil$ & 1, י & r,rVA & 11 & 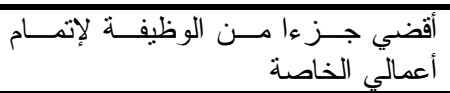 & \\
\hline كبيرة & $V \varepsilon, \varepsilon$ & $1, \cdot \leqslant 7$ & $r, v r$. & $r$ & بالعمل نفسي مثالا يحتذى به في الالتــز ام & \\
\hline قليلة & $7 T, \wedge r$ & $1, r \leqslant 0$ & $r, r \leqslant 1$ & 9 & تزيد المكافأة من نشاطي في العمل & \multirow{3}{*}{ 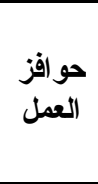 } \\
\hline منعدمة & $r r_{,} \varepsilon$ & $\cdot, \wedge \wedge \varepsilon$ & $1,7 Y r$ & $r$ & أجور العمل التي أتقاضـاها تكفيني & \\
\hline منعدمة & $\sum \Lambda, \vee \wedge$ & $1,1 \cdot 1$ & $r, \varepsilon r q$ & 17 & تقارير الأداء المقدمة للعاملين تعتمد علـى & \\
\hline قليلة & 74,74 & 1,191 & $r, I \wedge r$ & $1 \cdot$ & للحو أفحس للعمل بعد وضع نظام عــادل & \multirow{3}{*}{ 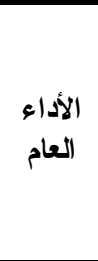 } \\
\hline قليلة & $7 \cdot, \leqslant \wedge$ & $1,1 \vee 7$ & $r, \cdot r \varepsilon$ & ir & أقلدم أفكار ا جديدة لعملي عندما تشجعني & \\
\hline قليلة & $T V, r Y$ & 1,98 & r, זד & $\Lambda$ & 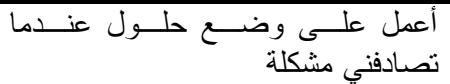 & \\
\hline
\end{tabular}

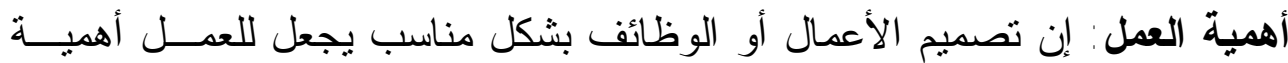

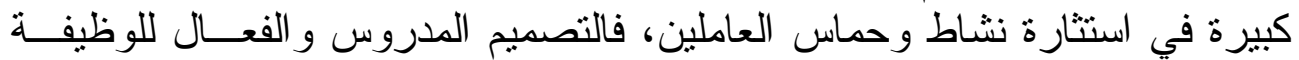

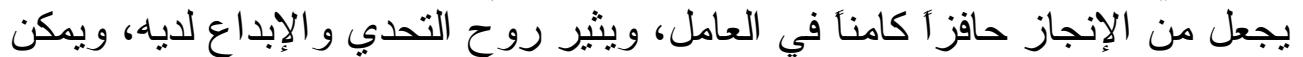

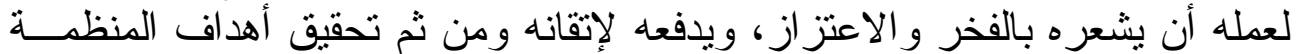

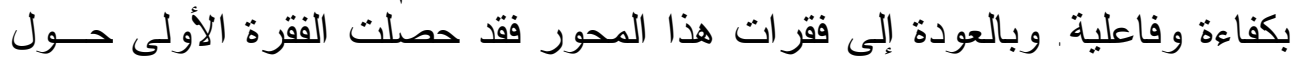

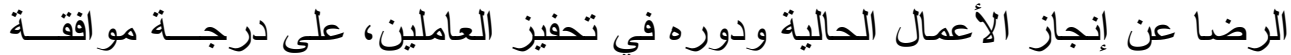

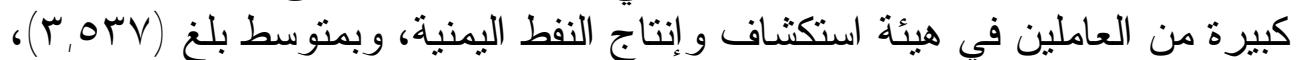

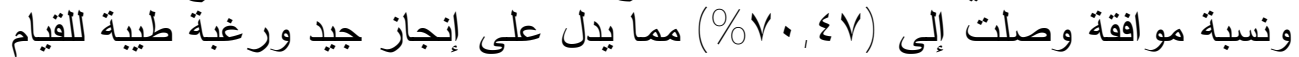

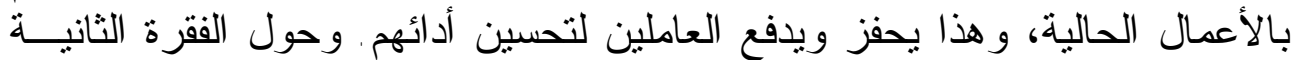

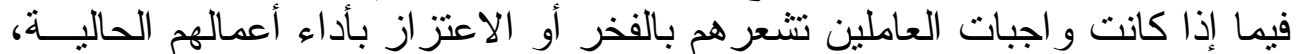

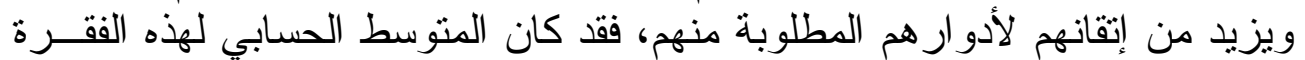

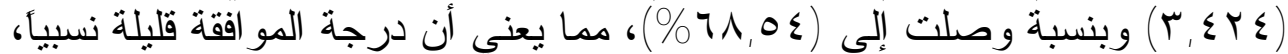

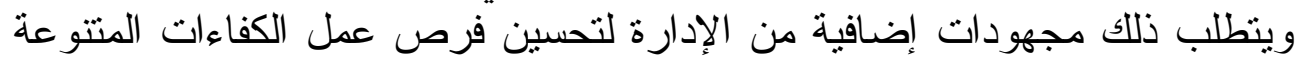

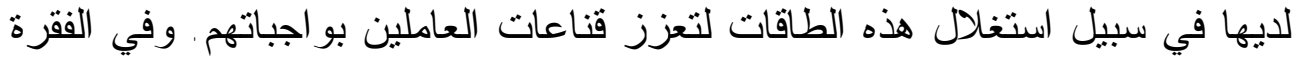

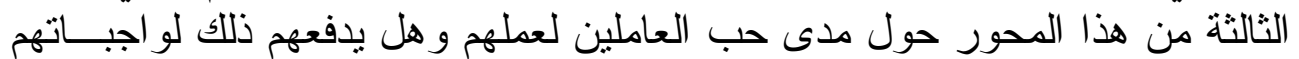
بحماس أكبر، فقد حصلت هذه الفقرة على نسبة مو افقة كبيرة بلغـــت ( 
وبمتوسط وصل إلى (Y,AlV) و وهذا يفيد بحب العاملين لأعمالهم الحالية مما يقوي

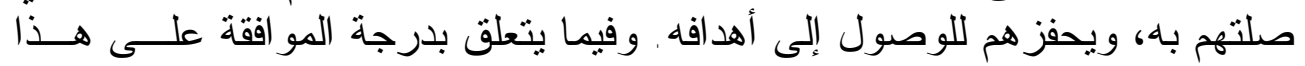

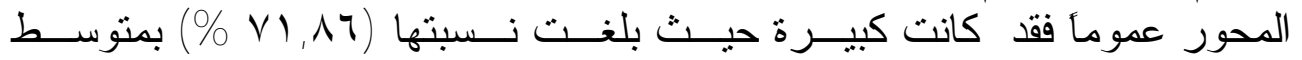

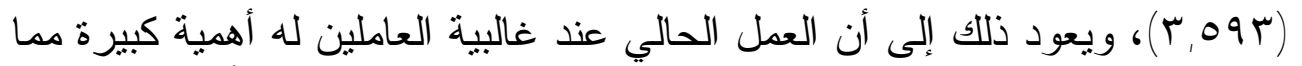

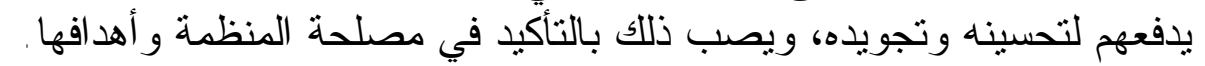

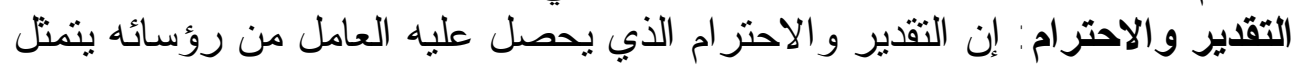

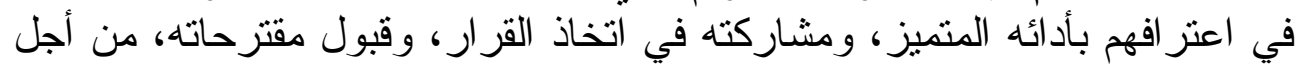

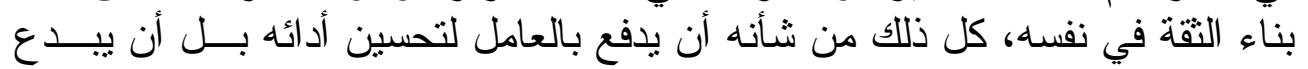

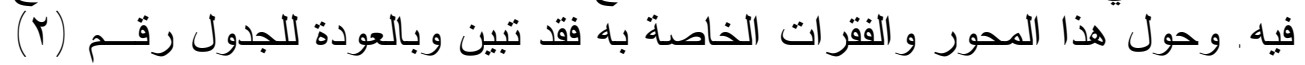
عند سؤ ال العينة حول مدى تقدير الرؤساء للعاملين وتأثثر ذلاء فئ في الأداء، فقد كانت

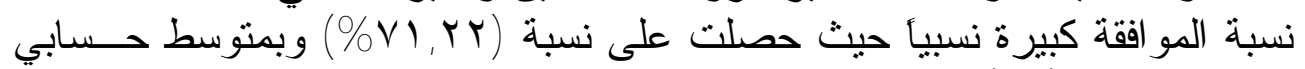

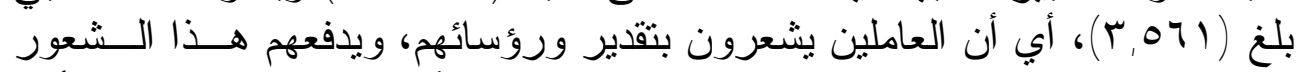

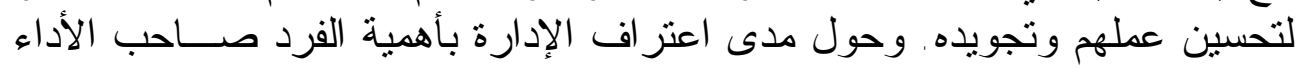

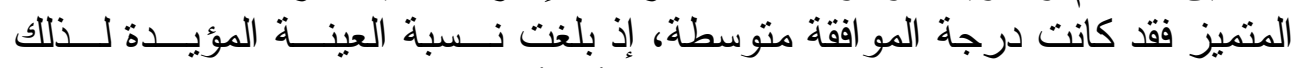

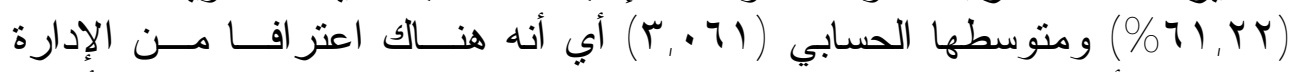

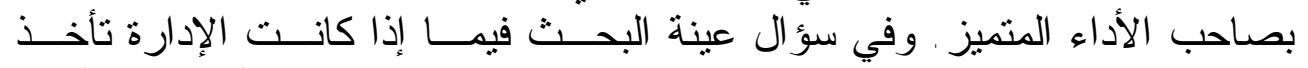

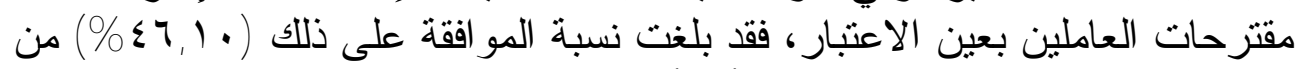

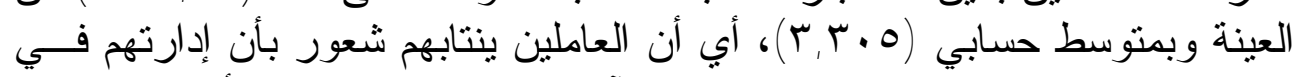

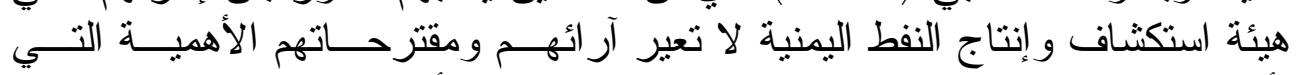

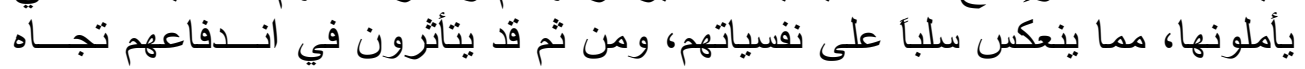

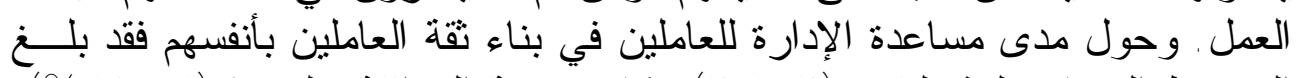

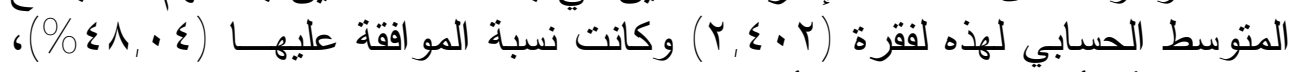

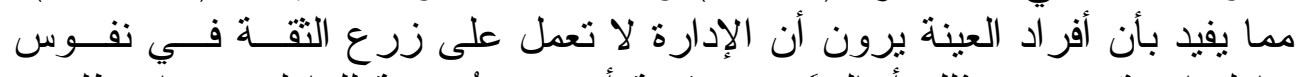

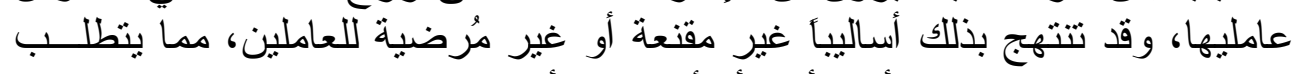

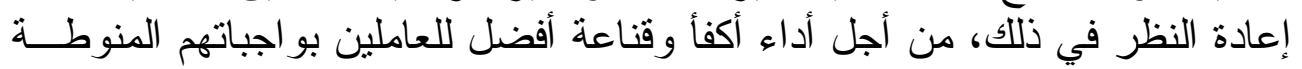

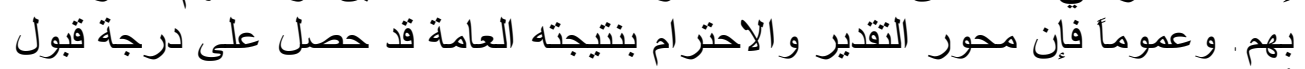

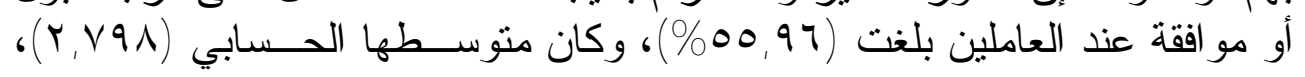

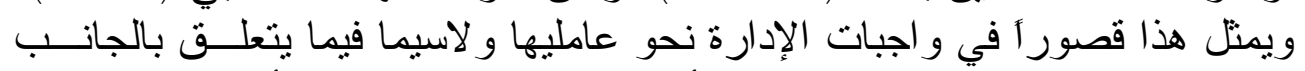

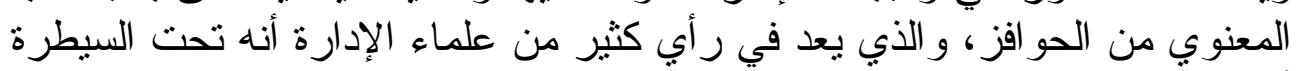

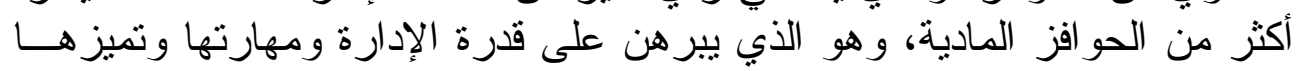
عن غير ها.

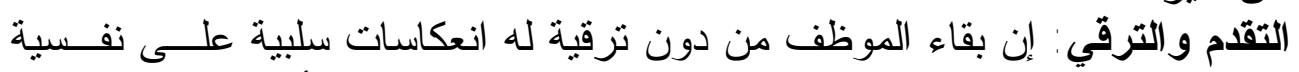

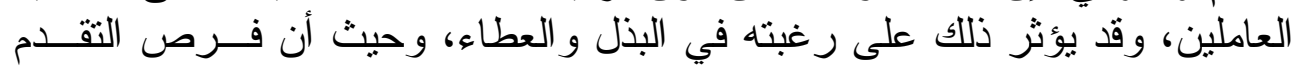

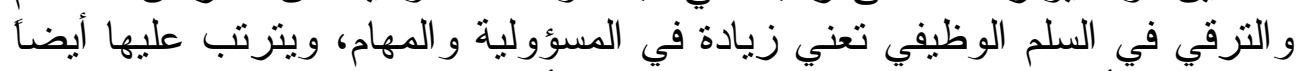

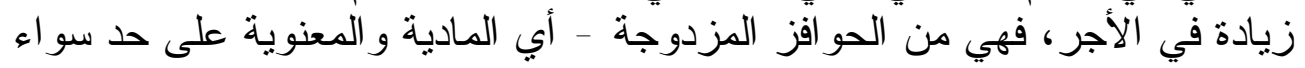

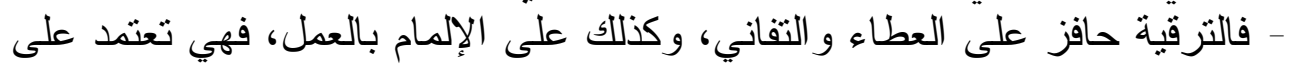




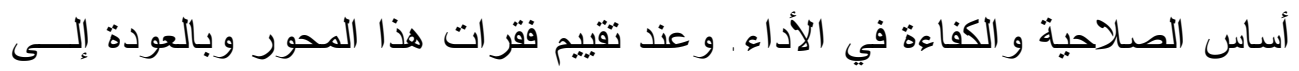

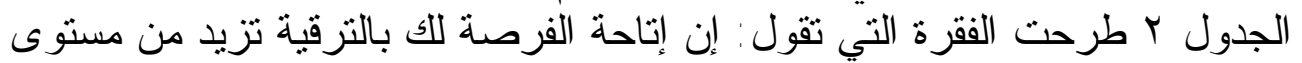

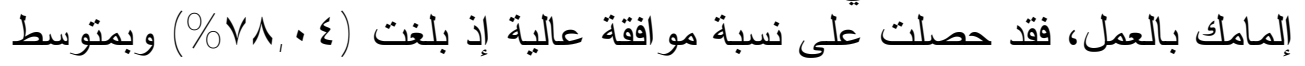

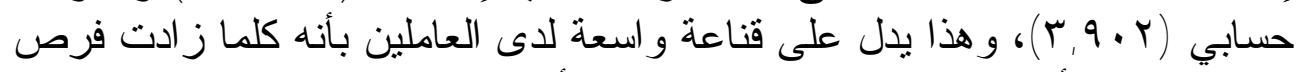

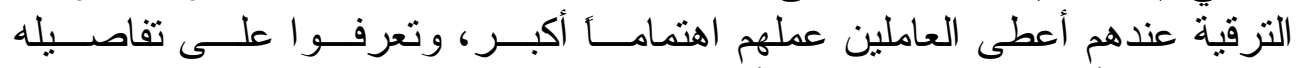

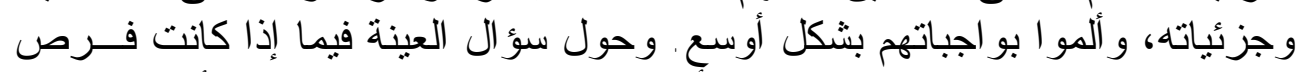

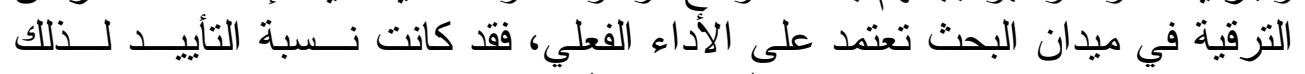

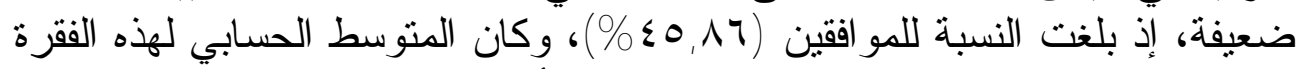

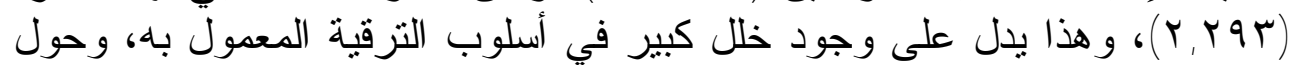

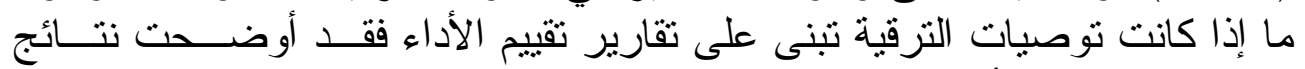

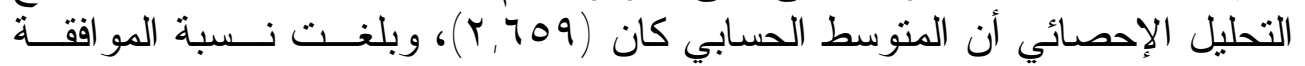

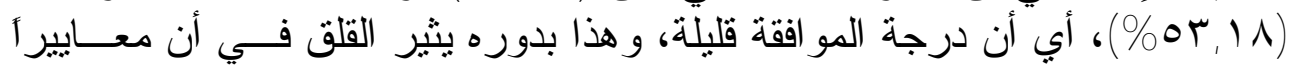

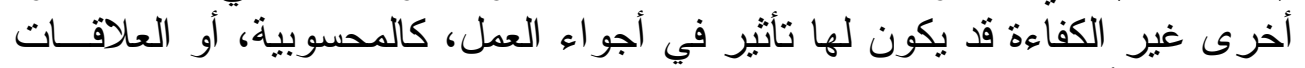

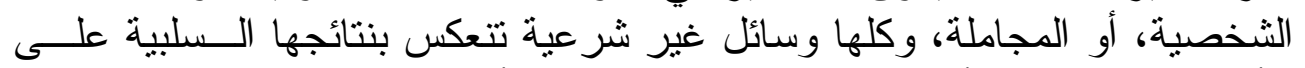

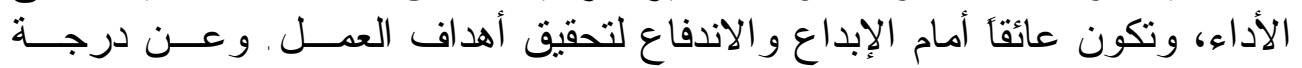

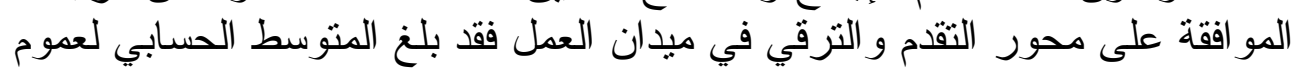

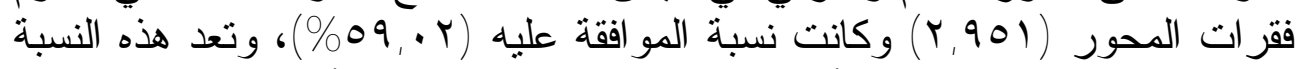

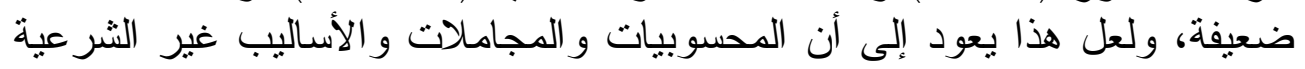

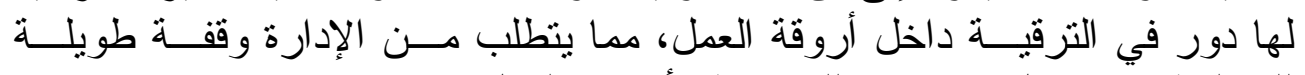

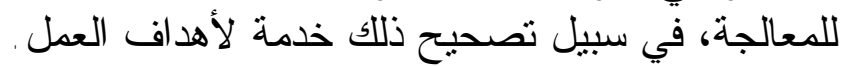

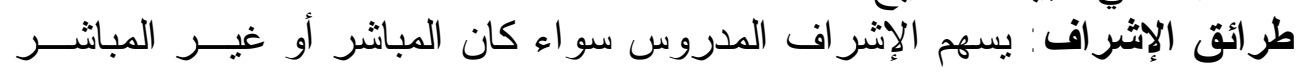

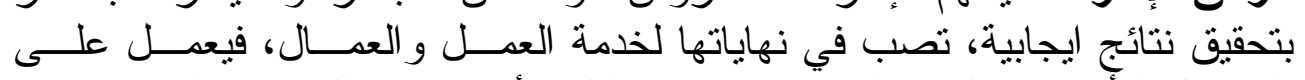

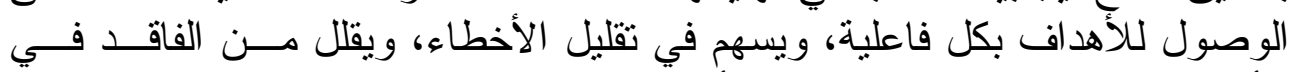

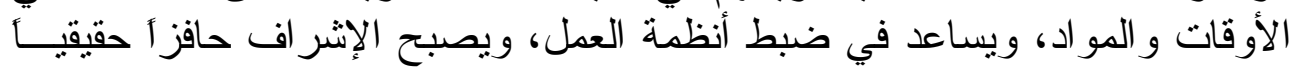

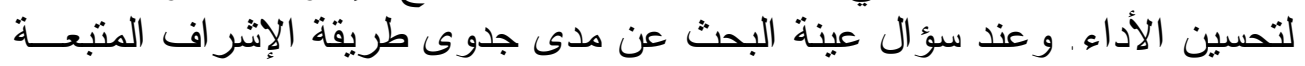

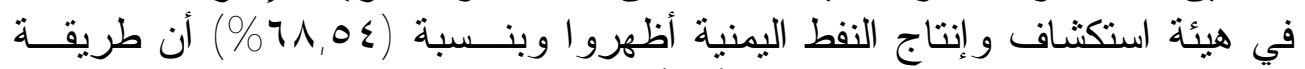

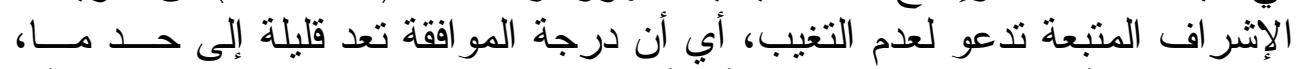

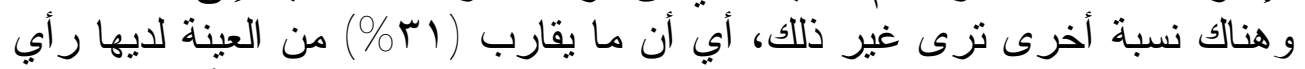

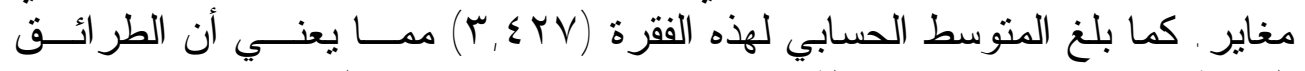

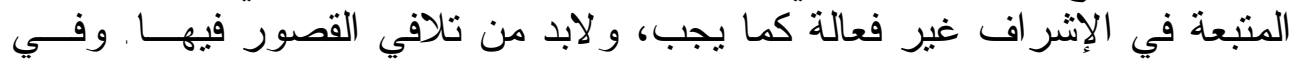

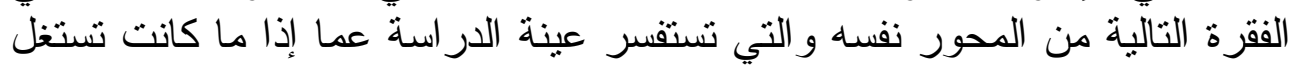

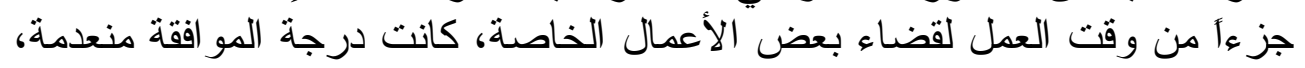

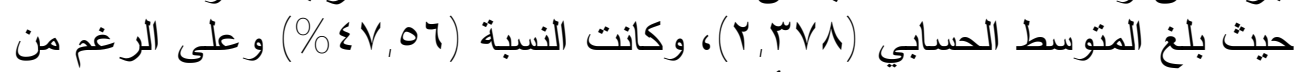

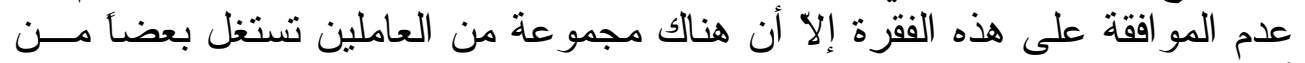

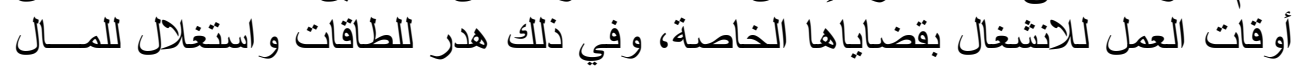

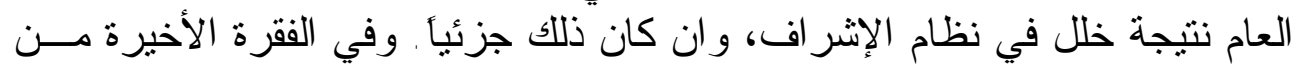


هذا المحور و التي تدور حول إمكانية أن يكون العامل مثالا يحتذى به في العمل في الإني

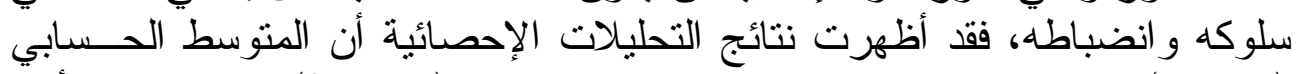

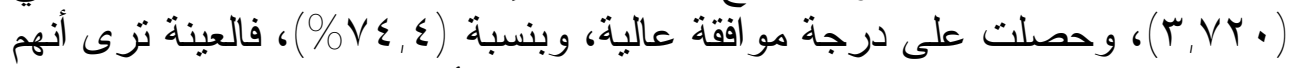

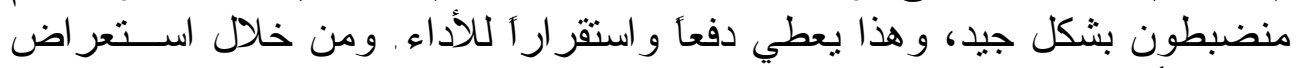

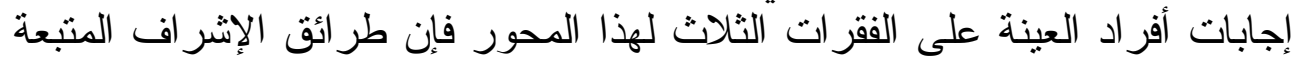

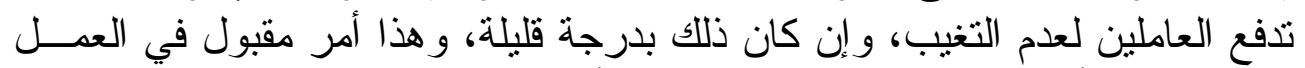

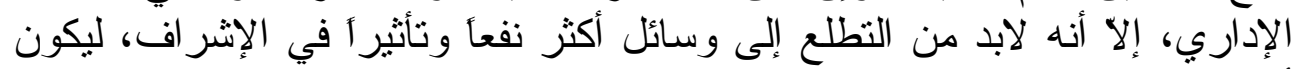

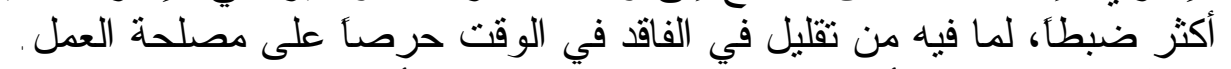

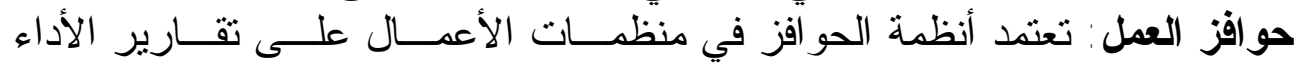

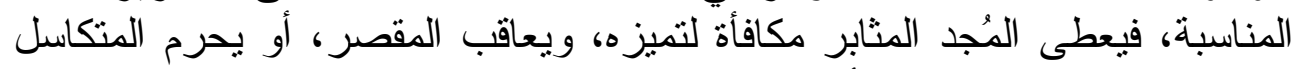

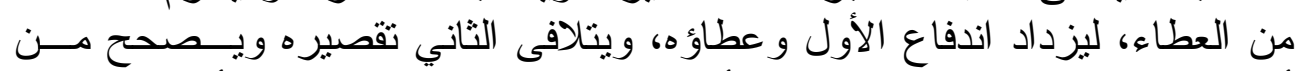

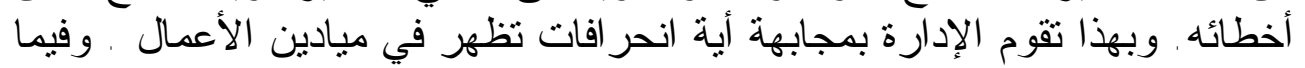

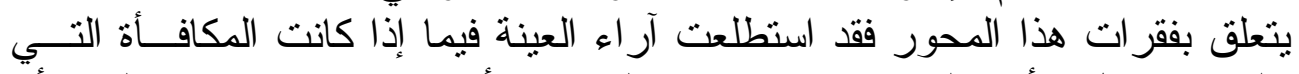

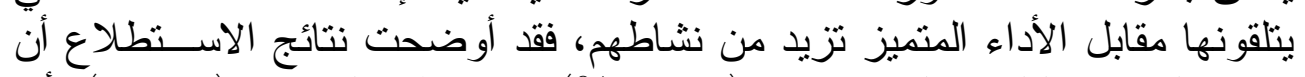

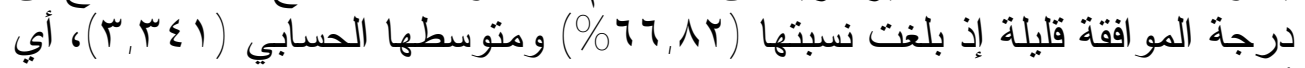

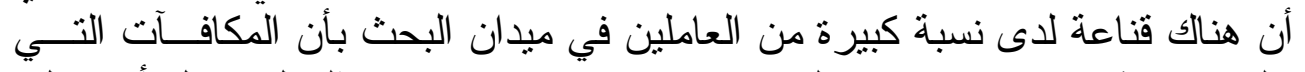

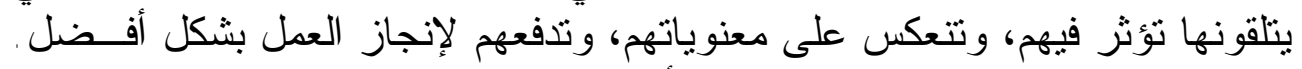

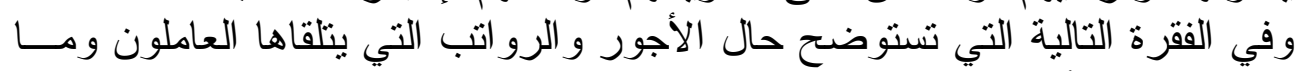

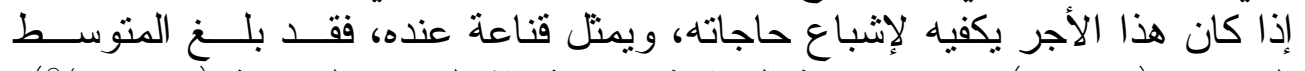

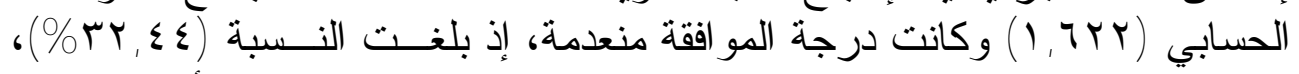

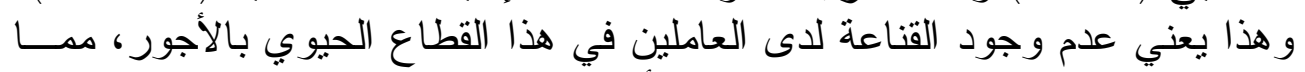

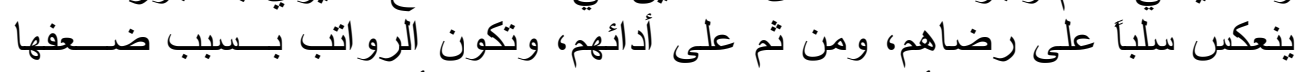

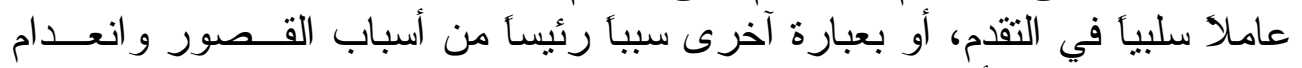

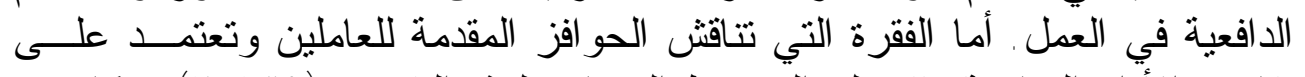

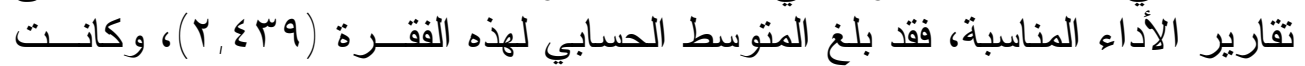

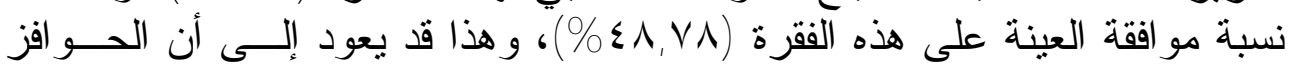

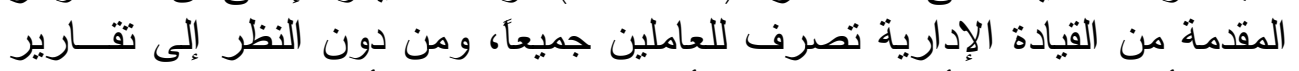

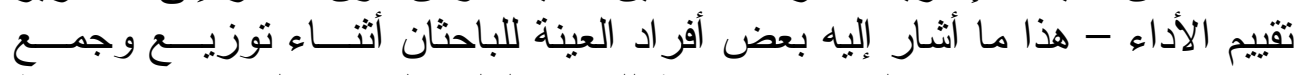

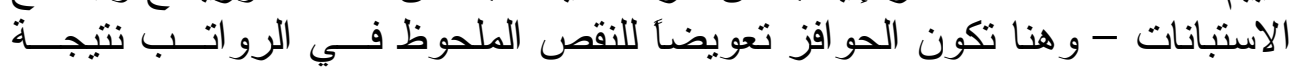

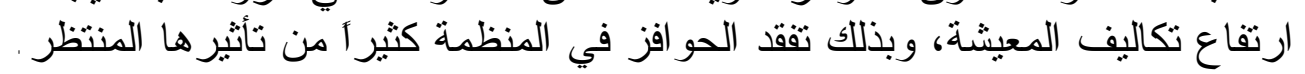

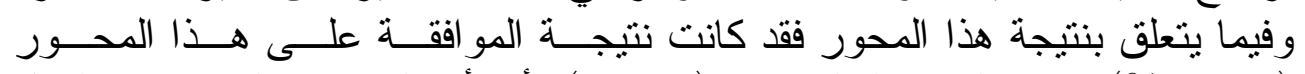

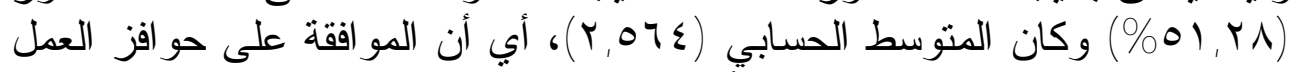

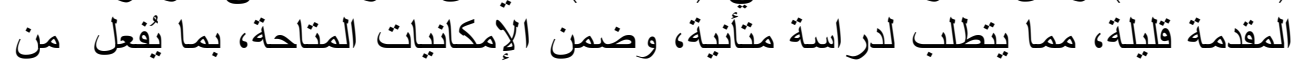

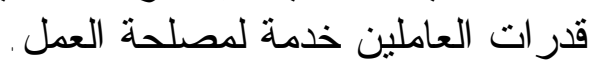

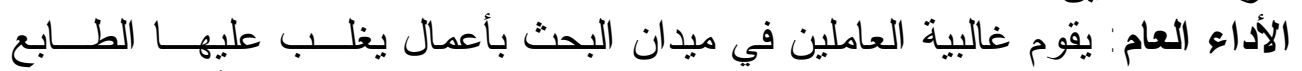

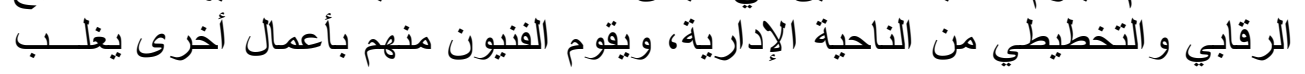




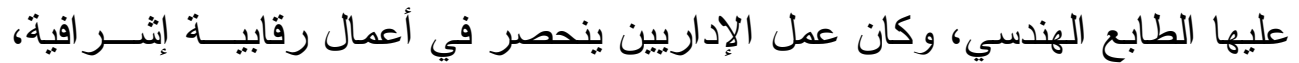

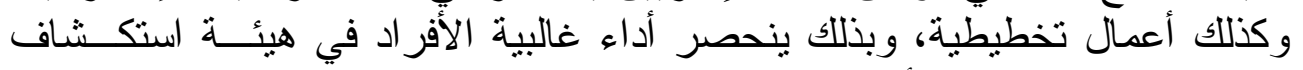

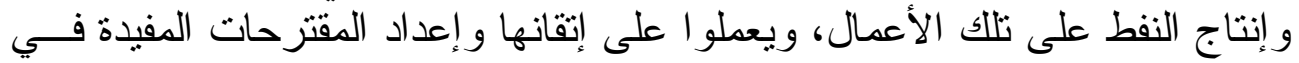

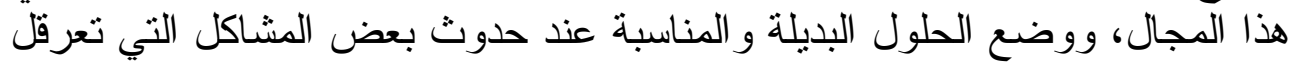

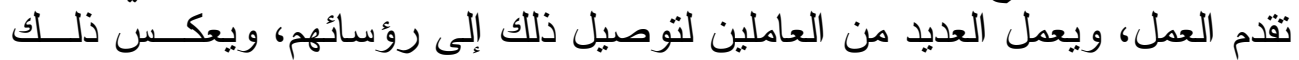

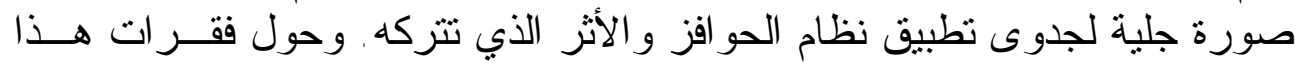

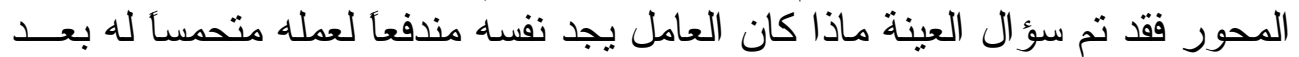

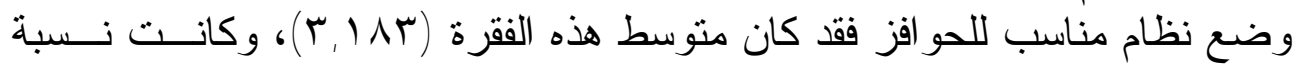

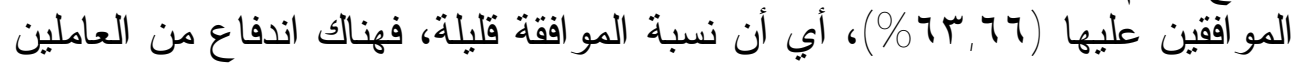

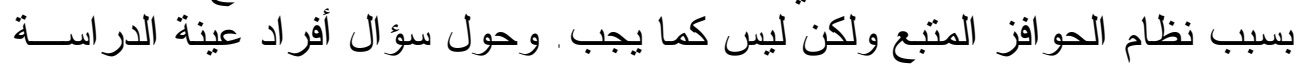

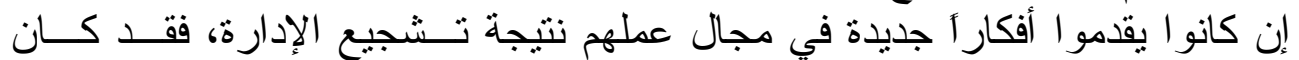

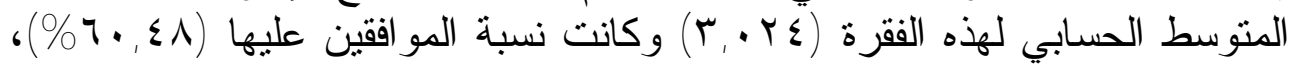

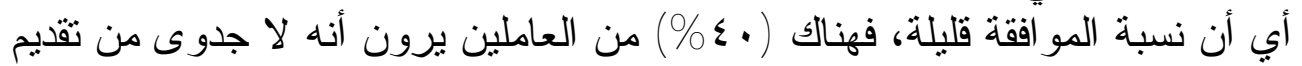

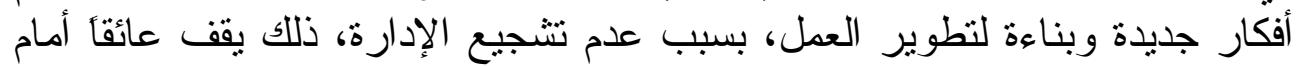

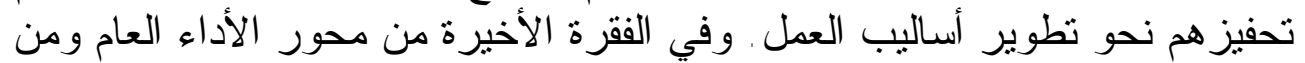

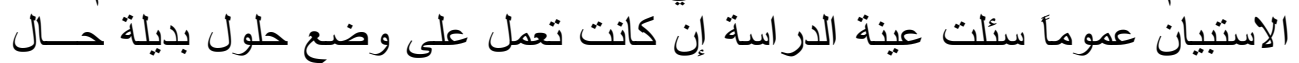

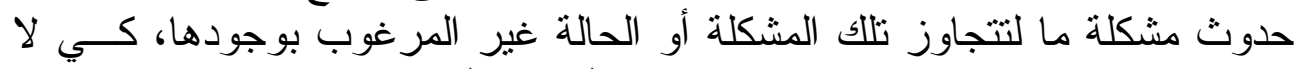

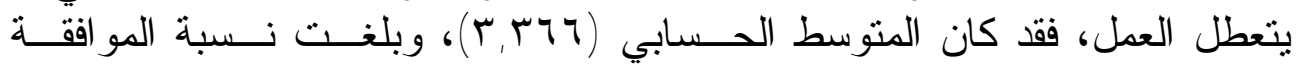

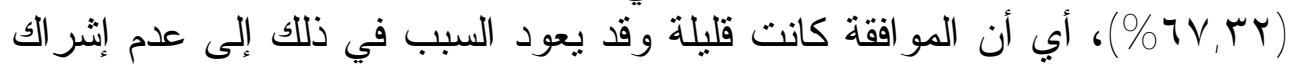

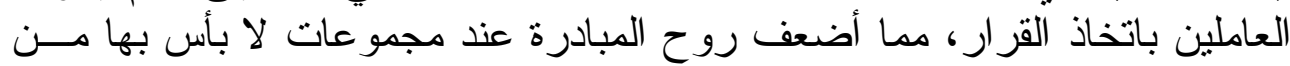

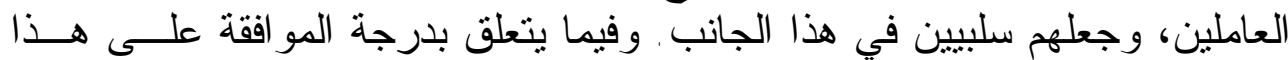

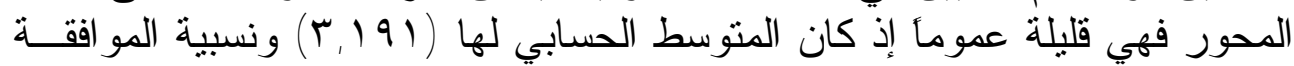

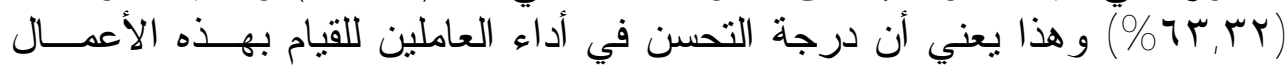

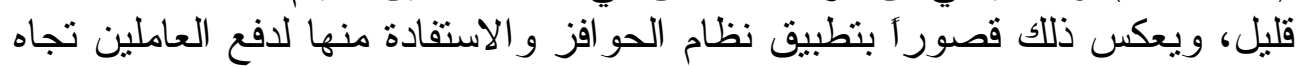

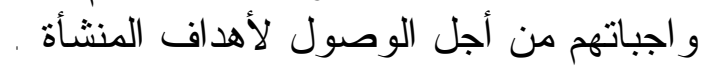

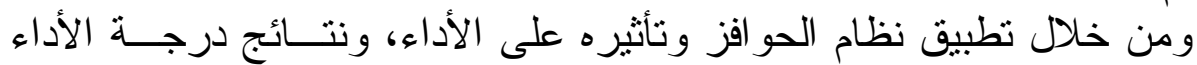

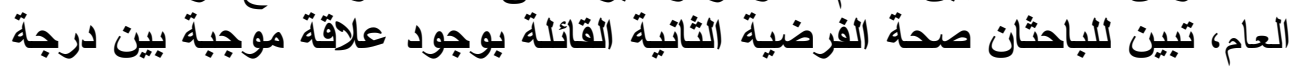
تطبيق نظام الحوافز ودرجة الأداء العام .

الآراء حول تطبيق نظام الحوافز حسب المتغيرات الثخصية

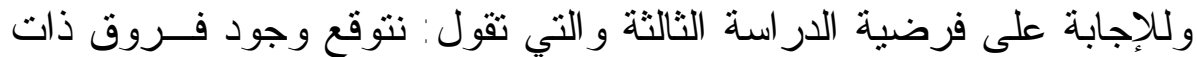

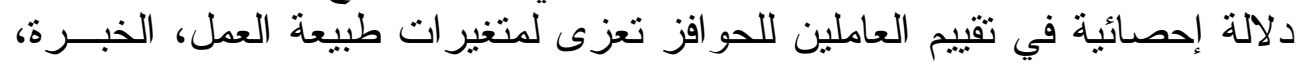

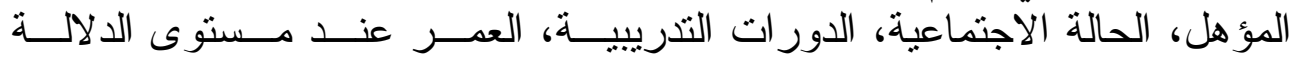

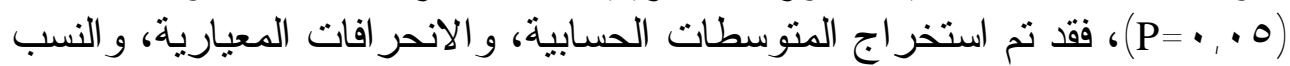

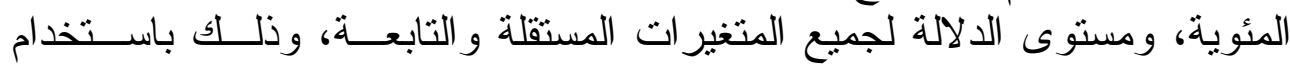

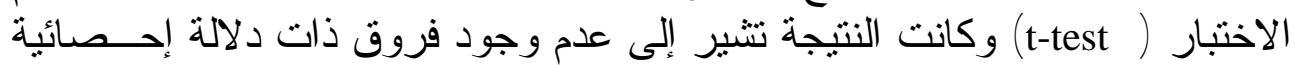




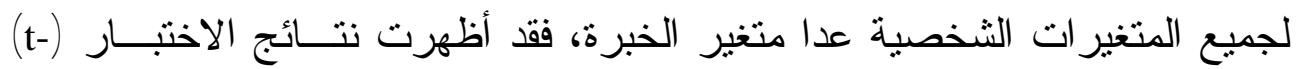

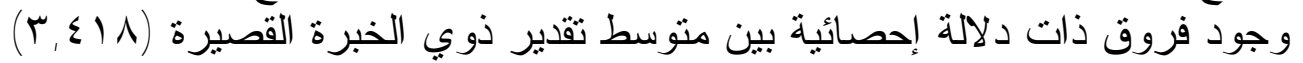

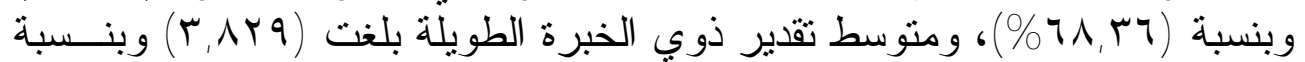

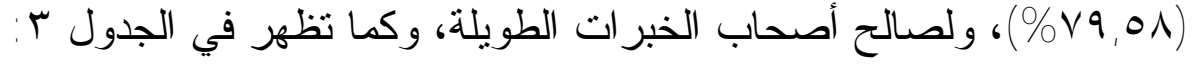

\begin{tabular}{|c|c|c|c|c|c|c|c|}
\hline \multicolumn{8}{|c|}{ الجدول r } \\
\hline مستوى & قيمة"ت" & الحرية & الأصحرب & لأصحاب الخبرة & أصناب الخبرة & متوسط أصحاب & المتغير \\
\hline.$r \varepsilon$ & $-r, 10$ & त. &.$\Delta r \varepsilon$ &. ATV & $r, \wedge r q$ & $r, \xi 1 \wedge$ & الخبرة \\
\hline
\end{tabular}

وهذا يعني رفض الفرضية الثالثة التي اقترحها الباحثان . خاتمة البحث و واستنتاجاته

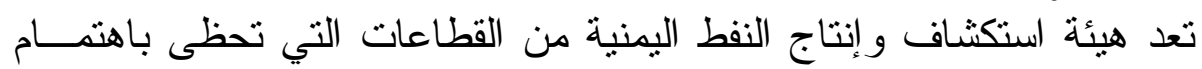

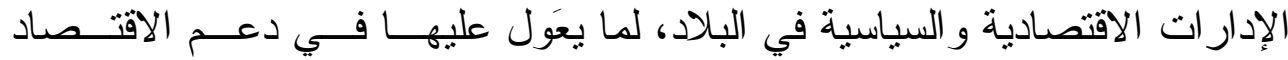

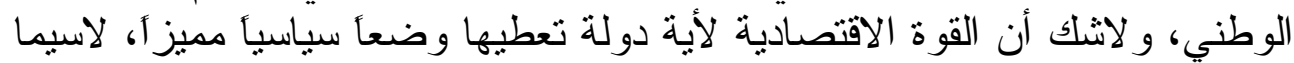

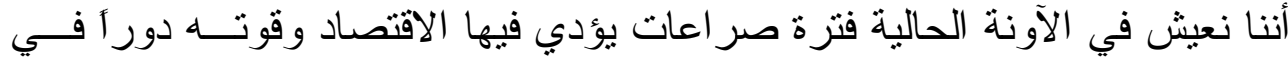

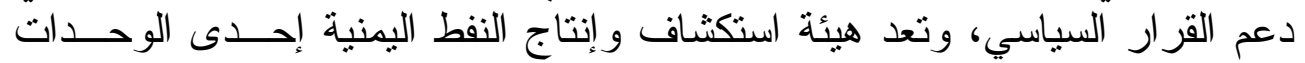

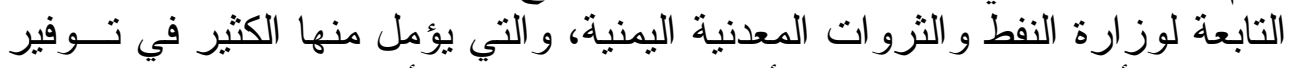

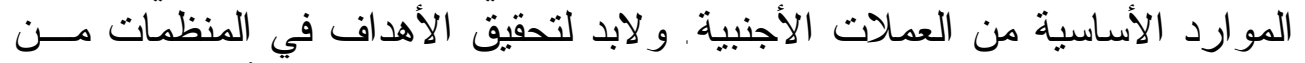

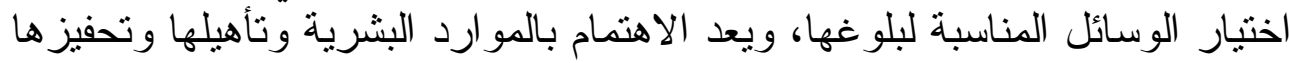

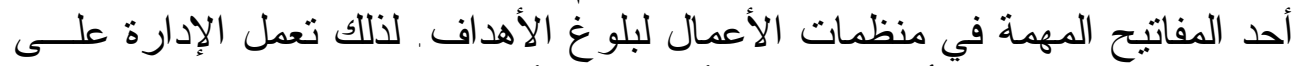

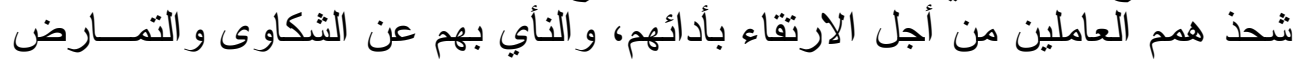

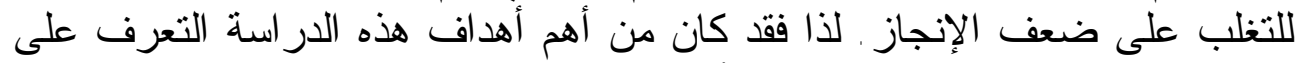

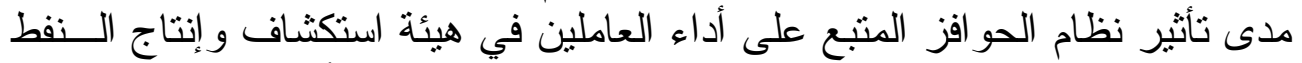

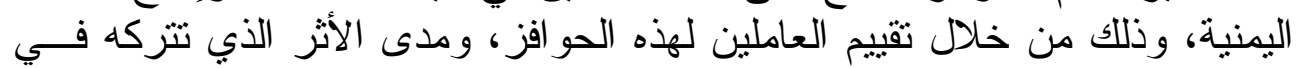
نفوسهم من أجل تحسين الأداء.

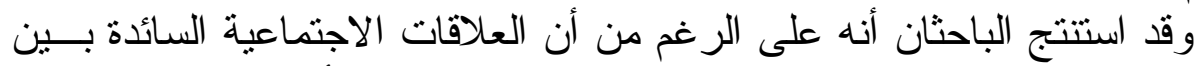

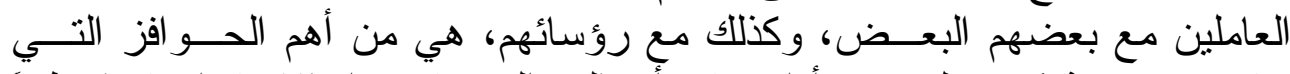

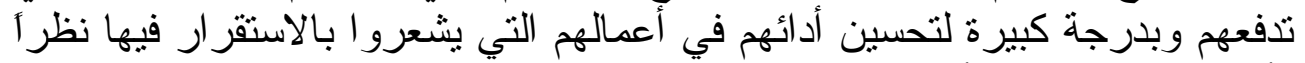

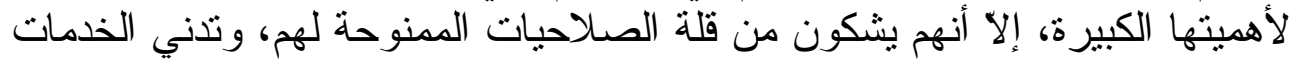

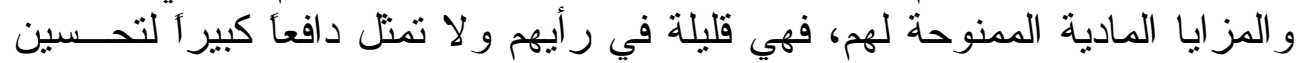

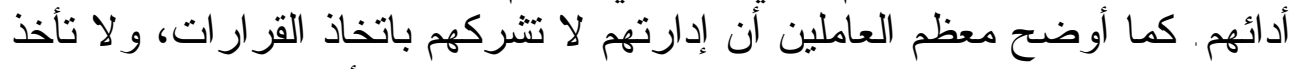

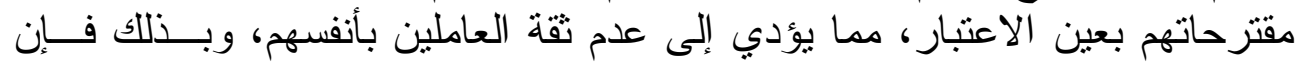

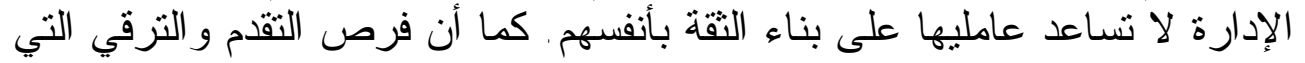


تمنحها الإدارة في هيئة استكثاف و إنتاج النفط اليمنية قليلة، و لا تحفز العاملين فيها

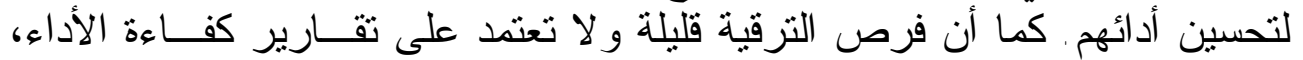

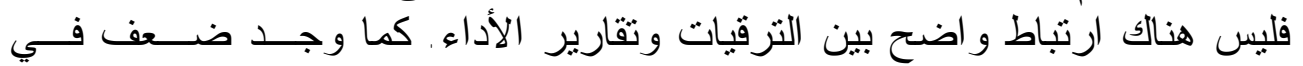

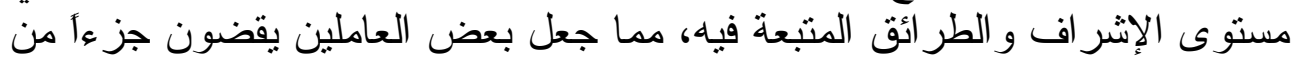

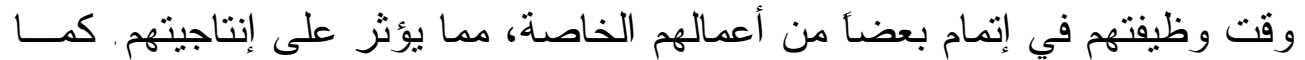

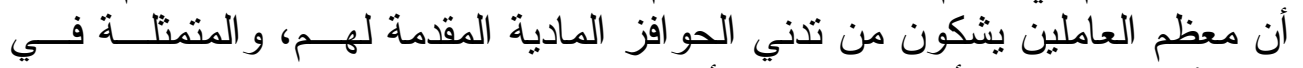

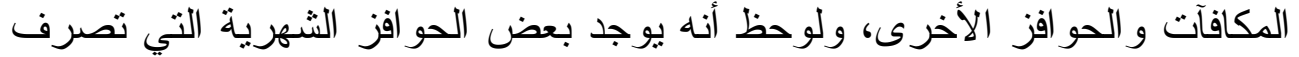

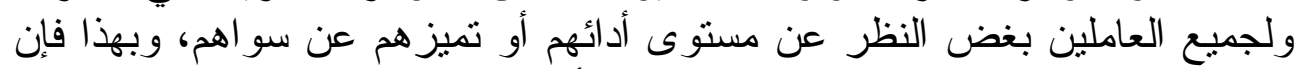

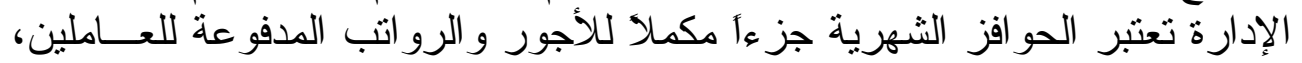

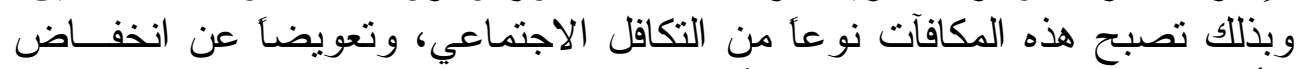
الأجر ، فتقة بذلك عامل التحفيز المأمول منها. ويتضح مما سبق أن درجة تطبيق نظام الحو افز قليلة، ودرجة التحسن فئن فئسي

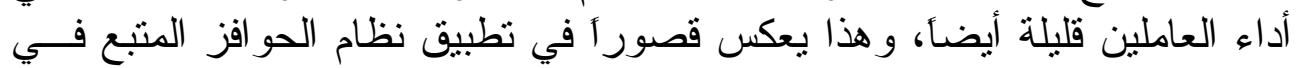

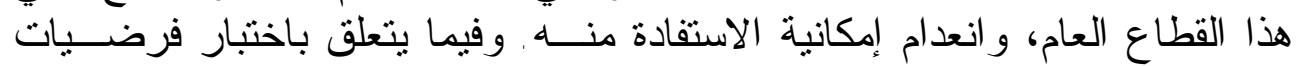

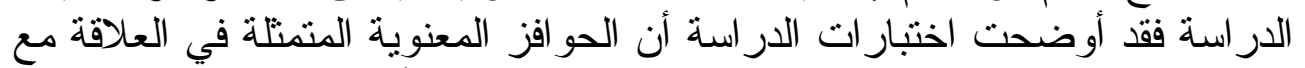

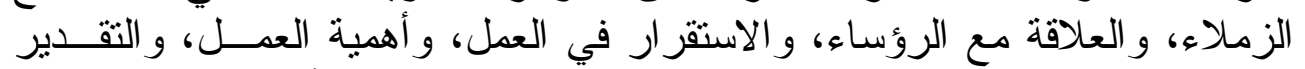

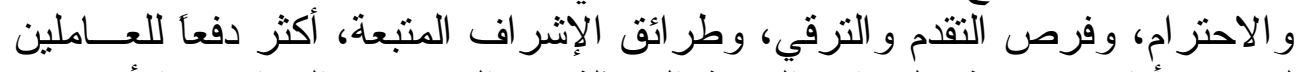

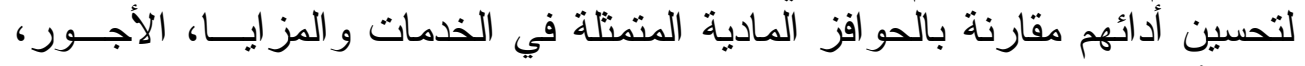

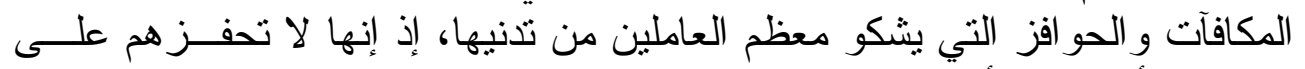

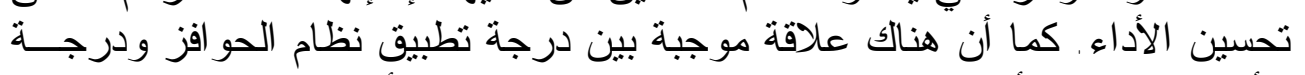

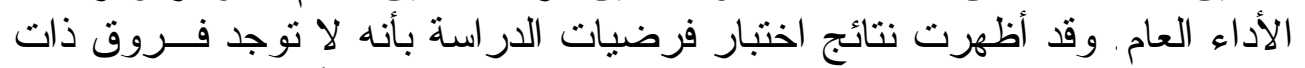

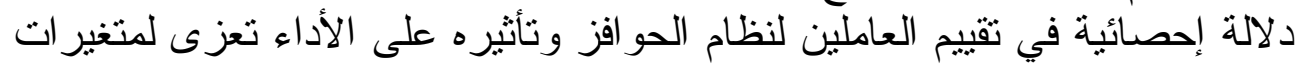
الدر اسة عمومأ.

اعتمادآ على نتائج التحليل لمعطيات هذه الدر اسة ونتائجها يمكــن صــياغة توصيات البحث

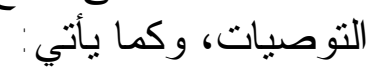

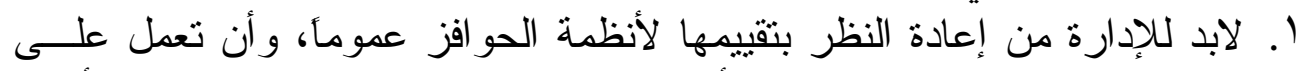

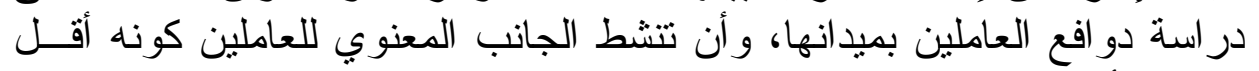
تكلفة، و أكثر فاعلية.

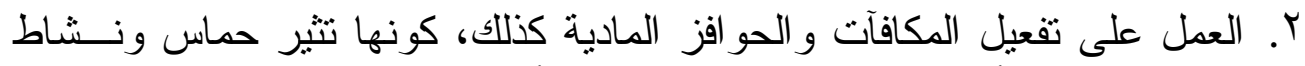

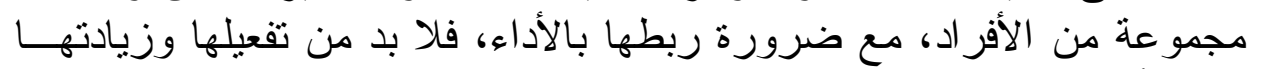

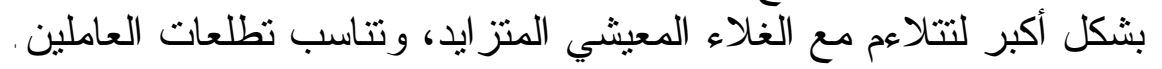

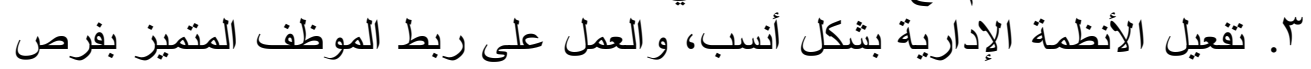

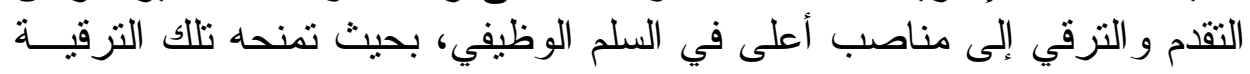




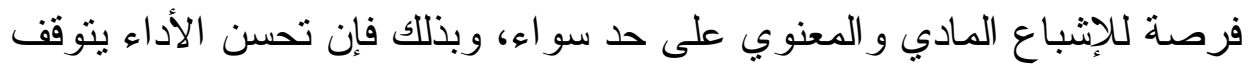

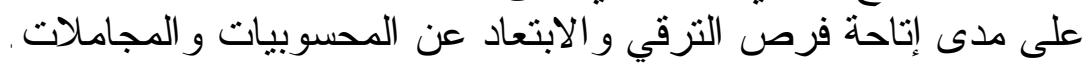
ء. العمل على غرس الولاء التتظيمي، وذللك من خلال إثر الك العاملين في اتخــاذ

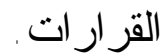
๑. للإنسان مكانة سامية وعالية في جميع المجالات، وقد رفع الله سبحانه وتعـالى الإنى

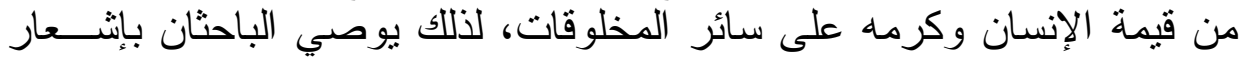

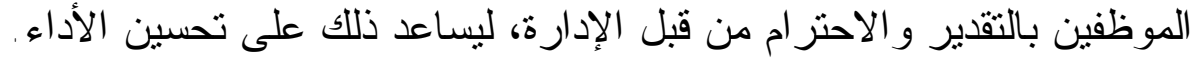

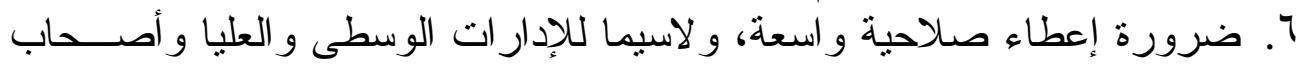

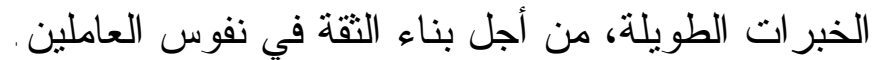
^. الاهتمام بالجو انب التطبيقية في الدورات التدريبية من أجل تحسين أداء العاملين .

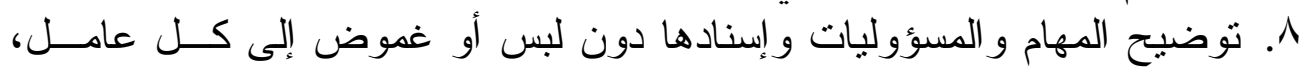
و إبعادهم عن الاتكالية على الغير في إنجاز الأعمال.

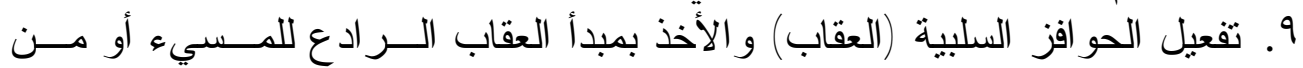

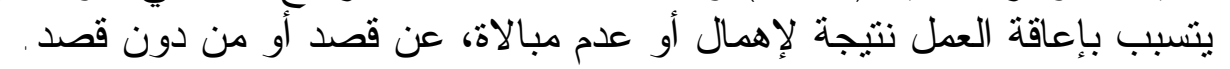

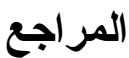 \\ أولاً - المراجع باللغة العربية}

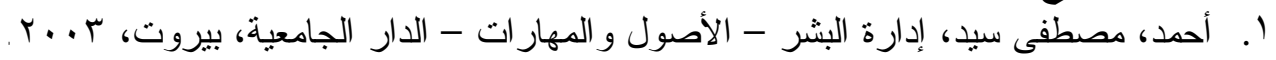

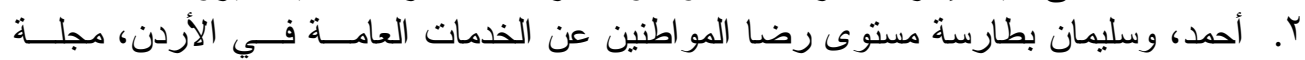

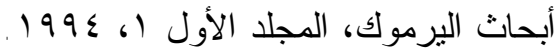
r. برير ، كامل، إدارة المو ارد البشرية وكفاءة الأداء التتظيمي، المؤسسة الجامعيــة للار اســات،

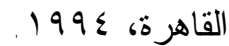

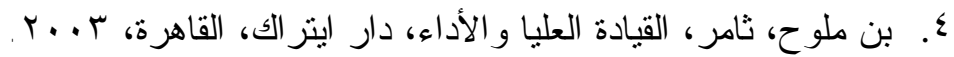

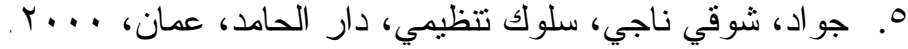

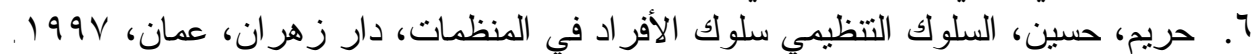

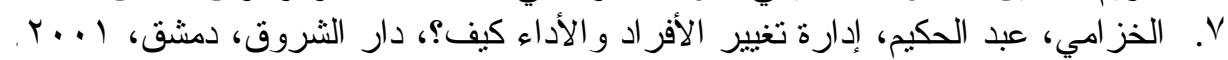

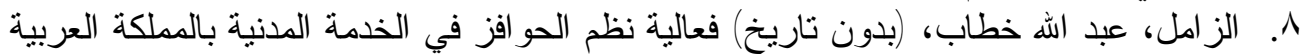

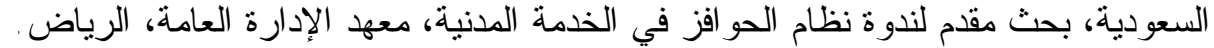

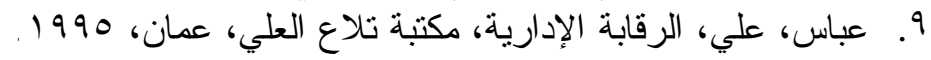

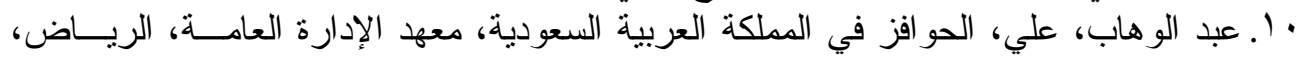
.1991

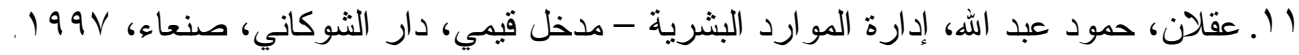

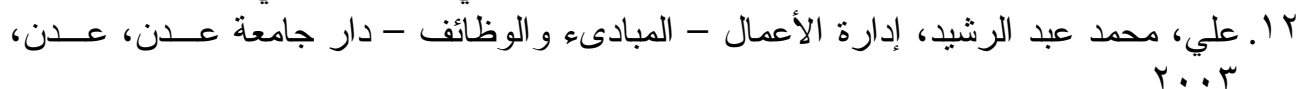

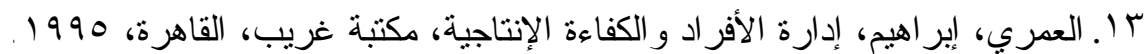

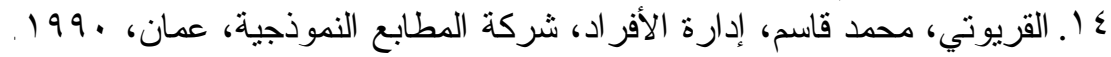




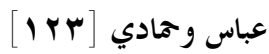

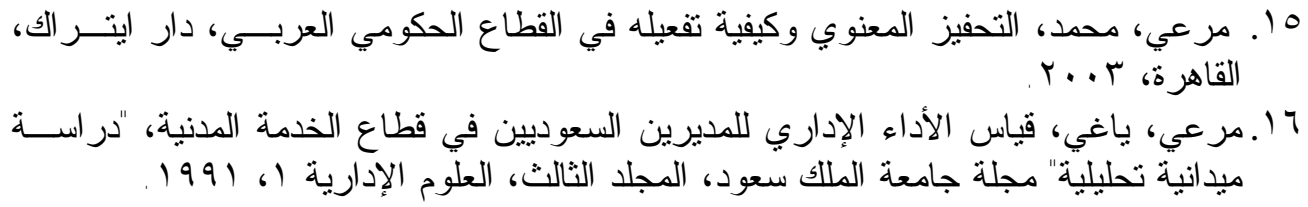

\section{ثانياً - المراجع باللغة الأجنبية}

1. Argyle M.et.al. Social Situations - Cambridge University Press - London,1991.

2. Boulding K. Conflict and Defense - Harper - London, 1982.

3. Howe L.W.\& Howe M.M. Personalizing Education Hant. - New York,1995.

4. Reagan, M. A Study of Job Satisfaction of the Faculties of the Colleges of Education at Michigan,s Three Universities Dissertation Abstracts International (2) (47),1986 . 